\title{
COMMENT
}

\section{THE ROLE OF GAO AND COURTS IN GOVERNMENT CONTRACT "BID PROTESTS": AN ANALYSIS OF POST-SCANWELL REMEDIES}

The procurement system operated by the government of the United States is the largest business in the world. ${ }^{1}$ In the first five months of fiscal year 1971-72, the total military procurement expenditures alone were $\$ 14.2$ billion. $^{2}$ The importance of government contracts in the national economy is, therefore, immediately apparent. On a smaller scale, whether or not an individual business can obtain a government contract could mean its survival or demise, and, in turn, determine the future employment or unemployment of entire communities of workers. ${ }^{3}$ Since the award of a government contract can have such an important economic impact, every bidder for a government contract is naturally interested in receiving fair treatment by the procuring agency. ${ }^{4}$ Likewise, if an unsuccessful bidder feels

1. P. Dembling, General Counsel, GAO, United States Government Contract Formation 1 (unpublished address before the ABA, London, England, July 14, 1971).

THE FOLLOWING HEREINAFTER CITATIONS WILL BE USED IN THIS COMMENT:

P. Dembling, General Counsel, GAO, Bid Protest Techniques (unpublished address before the National Contract Management Ass'n, Washington, D.C., September 15, 1971) [hereinafter cited as Bid Protest Techniques];

P. Dembling, General Counsel, GAO, Judicial and GAO Review of Bid Protest Cases (unpublished address before the Federal Bar Ass'n and JAG Officers, Wright-Patterson Air Force Base, Dayton, Ohio, May 20, 1971) [hereinafter cited as Judicial and GAO Review of Bid Protest Cases];

Cibinic \& Lasken, The Comptroller General and Government Contracts, 38 Geo. WAsH. L. REV. 349 (1970) [hereinafter cited as Cibinic \& Lasken].

2. 421 BNA FED. CoNT. REP. A-5 (1972). Military procurement expenditures for fiscal year 1970-71 totaled \$34.5 billion, and for fiscal year 1969.70 totaled \$36 billion. 399 BNA FED. CONT. REP. A-5 (197I). In fiscal year 1969-70, federal procurements, both military and civilian, totaled $\$ 55$ billion. Address by P. Dembling, supra note 1 , at 1 .

3. The economic significance of government contracts has been noted most recently in the defense-oriented and aerospace industries. See generally N.Y. Times, Dec. 18, 1971, at 31, col. 7; id., Nov. 23, 1971, at 62, col. 3 .

4. In awarding government contracts, the procuring agencies are required to follow certain procedures and practices prescribed by Congress. See, e.g., Armed Services Procurement Act 
that he has not received fair treatment, he will want an expeditious remedy.

The availability of remedies, however, has largely been influenced by the holding of the Supreme Court in Perkins v. Luken Steel Co. ${ }^{5}$ that no one has a right to a government contract, inasmuch as the procurement statutes were enacted for the benefit of the government and not the bidder. ${ }^{6}$ As a result, courts consistently refused to hear complaints against the alleged illegal activity of the officials of procuring agencies. ${ }^{7}$ Not only was the judicial forum closed to the unsuccessful bidder, but the procuring agencies themselves had no formalized procedure for handling complaints. ${ }^{8}$ However, the General Accounting Office (GAO) was established prior to the Supreme Court's decision in Perkins, ${ }^{9}$ and shortly after its establishment, the Comptroller General of the GAO began to hear and decide cases brought

of 1947, 10 U.S.C. $\$ 2301-14$ (1970); Federal Property \& Administrative Services Act of 1949 , 41 U.S.C. \$ 5, 251-55, 257-60 (1970). See also Armed Services Procurement Regulations, 32 C.F.R. ch. I (1971); Federal Procurement Regulations, 41 C.F.R. ch. 1 (1972). The procurement statutes prescribe two methods of procurement-formal advertising and negotiation. Procurement by formal advertising is the general method to be used, with negotiation allowed only in specifically listed exceptions. 10 U.S.C. § 2304 (1970); 41 U.S.C. § 252(c) (1970). However, in terms of dollars spent, 85 percent of military procurements and 66 percent of civilian procurements have been accomplished by negotiation. Dembling, supra note 1 , at 6 . Procurement by formal advertising is a procedure under which (1) invitations for bids with detailed and definite specifications are prepared and publicly advertised, (2) sealed bids are submitted by prospective contractors, (3) these sealed bids are then publicly opened, and (4) the award is made to the bidder who agrees in his bid to conform to the invitation for bids, whose price is low, and who is determined to be capable of performing the contract. 32 C.F.R. $\S 2.101$ (1971), 41 C.F.R. § 1-2.101 (1972). The term "negotiate" is defined simply as to "make [the contract] without formal advertising." 10 U.S.C. § 2302(2) (1970). Therefore, it embraces a wide variety of possible procedures. See 32 C.F.R. $\$ 3.101$-.102 (1971); 41 C.F.R. $\$ 1$ $3.101-.102$ (1972).

5. 310 U.S. 113 (1940).

6. Id. at 126.

7. E.g., Friend v. Lee, 221 F.2d 96, 100 (D.C. Cir. 1955); Fulton Iron Co. v. Larson, 171 F.2d 994, 997-98 (D.C. Cir. 1948), cert. denied, 336 U.S. 903 (1949); Walter P. Villere Co. v. Blinn, 156 F.2d 914, 916 (5th Cir. 1946); Heyer Prods. Co. v. United States, 140 F. Supp. 409, 412 (Ct. Cl. 1956).

8. Compare notes 19-21 infra and accompanying text with the procedures of the Armed Services Board of Contract Appeals which considers appeals from decisions of contracting officers concerning disputes which arise during the performance of government contracts. For a discussion of the procedures of the Board of Contract Appeals, see 3 CCH Gov'r CoNT. Rep. II $23,300-350$ (1972).

9. The GAO was established by the Budget \& Accounting Act of 1921 , 31 U.S.C. $\$ 41$ (1970). In 1925 the GAO decided its first bid protest case on the merits. Judicial and GAO Review of Bid Protest Cases 1. 
by the unsuccessful bidder. ${ }^{10}$ For over 45 years bidders viewed the GAO as the sole forum "[f]illing the vacuum left by judicial abandonment of the contract formation process ...."."1

A dramatic turnabout in judicial attitudes toward bid protests occurred in 1970 when the Court of Appeals for the District of Columbia decided the landmark case of Scanwell Laboratories, Inc. v. Shaffer, ${ }^{12}$ holding that a bidder for a government contract had standing under the Administrative Procedure $\mathrm{Act}^{13}$ to obtain judicial consideration of a claim of illegality in the award of a contract. This decision established a bifurcated system of relief-the GAO and the courts-for the unsuccessful bidder. ${ }^{14}$ Since the court in Scanwell opened the judicial forum for review of procurement decisions, a large number of cases have been brought under its authority. ${ }^{15}$ Initially, the district courts experienced some confusion over the appropriate standard of review as evidenced by the substantial number of reversals of the district court decisions by the courts of appeals. ${ }^{16}$ However, through a series of decisions culminating in $M$. Steinthal \& Co. v. Seamans ${ }^{17}$ and Wheelabrator Corp. v. Chaffee ${ }^{18}$ the Court of Appeals for the District of Columbia has eliminated much of the

10. Bid Protest Techniques 2. This development was based upon an carlier practice of allowing accounting officers, who settle and certify accounts of the United States, to obtain a decision with respect to the legality of a proposed payment prior to the time the officer made the payment. By this method the accounting officer protectcd himself from personal liability for illegal payments. This procedure was codified in the Dockery Act of 1894, 31 U.S.C. $\S 74$ (1970). It was further developed by giving to the hcad of a procuring agency or a contracting officer a decision determining the legality of a proposed contract award. Then, in 1925, the GAO dccided that it would consider protcsts by the bidder himself over a proposed contract award. Judicial and GAO Review of Bid Protest Cases 2; Cibinic \& Lasken 358-60, 376.

11. Cibinic \& Lasken 350.

12. 424 F.2d 859 (D.C. Cir. 1970).

13. 5 U.S.C. $\$ 702$ (1970). See notes $53-54$ infra and accompanying text.

14. Under its post-Scanwell policy, however, the GAO will not hear a case which is involved in litigation before a court of competent jurisdiction. E.g., Unpublished Opinion, B-170268, April I4, 1971; Unpublished Opinion, B-171 I22, Fcb. 9, 1971. 4 C.F.R. \& 20.11 (I972).

15. By May 1971, at least forty-five cases had been filed on the basis of the Seanwell holding. Judicial and GAO Review of Bid Protest Cases 22.

16. E.g., Wheelabrator Corp. v. Chafce, 455 F.2d 1306 (D.C. Cir. 1971); M. Stcinthal \& Co. v. Seamans, 455 F.2d 1289 (D.C. Cir. 1971); Allen M. Campbell Co. v. Lloyd Wood Const. Co., 446 F.2d 26I (5th Cir. 1971); A.G. Schoonmakcr Co. v. Resor, 445 F.2d 726 (D.C. Cir. 1971); Page Communications Eng'rs, Inc. v. Resor, I5 CCH ConT. CAS. F. II 84, I 54 (D.C. Cir., Dec. 4,1970$)$.

17. 455 F.2d 1289 (D.C. Cir. I971).

18. 455 F.2d 1306 (D.C. Cir. 1971). 
initial uncertainty and has delineated more precisely the role of the courts in providing relief to the unsuccessful bidder.

The purpose of this Comment is to describe the present posture of the bifurcated system of relief available to the unsuccessful bidder and to evaluate its adequacy. The impact of Scanwell and subsequent decisions upon the types and effectiveness of remedies, however, cannot be fully understood without first considering in more detail the system of relief as it existed before February, 1970.

\section{TyPes of Relief Prior to Scanwell}

Prior to the court's decision in Scanwell, three types of relief were available to a disappointed bidder who felt that the procuring agency had prejudiced him by failing to follow the procurement statutes or regulations: the bidder could file a protest with the procuring agency itself, with the GAO, or more recently, in the Court of Claims. The bidder generally utilized the available remedies in that order.

The procuring agencies have no formalized adjudicatory-type procedures for handling bid protests. The procedure outlined in the procurement regulations provides only that a complaint be submitted to the contracting officer, that notice be given to all other bidders so that they may submit whatever information they desire, and that the contracting officer give written notice of his decision. ${ }^{19}$ If no contract award has been made, the general policy expressed in the regulations is to withhold award pending resolution of the protest where practicable. ${ }^{20}$ However, a protest may be denied, even though a valid ground for sustaining exists, if the contract performance is already substantial. ${ }^{21}$

19. See, e.g., 32 C.F.R. $\S 2.407-9$ (1971), which obligates the contracting officer to give consideration to protests in advertised procurements. See also id. at $\S 3.509$, which applies the same rules to negotiated procurements. These regulations contain instructions on how to process a protest, but do not contain instructions for determining whether or not a protest is meritorious. For a general discussion of bid protests filed with the procuring agency, see G. Cuneo, Government Contracts Handbook 22 (1962); R. Nash, JR. \& J. Cibinic, JR., Federal Procurement LAw 965 (1969).

Since the existence of both a valid contract and a disputes clause is a necessary prerequisite to the jurisdiction of the Board of Contract Appeals, it does not have jurisdiction over bid protests. 3 CCH Gov'T CoNT. REP. II 23,055, 23,060 (1972); 1 J. MCBRIDE \& I. WACHTEL, GOVERNMENT CONTRACTS, $\$ \S 6.20[1], 6.40$ (1970). See 32 C.F.R. $\S 30.1$ (1971); Leventhal, Public Contracts and Administrative Law, 52 A.B.A.J. 35, 39 (1966). For a discussion of the disputes clause provisions, see $3 \mathrm{CCH}$ Gov'T CONT. REP. If 23,005 (1970).

20. 32 C.F.R. $\S 2.407-9$ (b)(3) (1971); 41 C.F.R. $\S 1-2.407-8(b)(4)$ (1972).

21. $1968 \mathrm{CCH}$ Government Contracts Gutde If 762. 
The GAO provides an independent forum for review of procurement activities.22 It has rendered bid protest decisions upon the theory that the statutory authority to settle all claims and demands against the United States ${ }^{23}$ and to settle the public accounts ${ }^{24}$ imposes, in turn, the duty to see that contracts involving the expenditure of public funds are legally made. ${ }^{25}$ The GAO has stated that bidding on a procurement contract is not a condition precedent to filing a protest; rather, the protest may be made by anyone with a legitimate interest. ${ }^{26}$ In order to be successful, however, the protestant must demonstrate that the procedure used by the procuring agency has adversely affected the government or that it would tend to harm the integrity of the competitive bidding system. ${ }^{27}$

GAO bid protest decisions are not binding upon the procuring

22. The GAO is not an executive agency; rather, it is part of the legislative branch and is an agent of Congress. Reorganization Act of 1945, ch. 582, 59 Stat. 616; Reorganization Act of 1949, 5 U.S.C. $\$ 133 z-5$ (1964), as amended 5 U.S.C. $\$ 902(1)$ (1970); 31 U.S.C. $\$ 65(d)$ (1970). For a general discussion of the role of the GAO in government procurement, see Birnbaum, Government Contracts: The Role of the Comptroller General, 42 A.B.A.J. 433 (1956); Cable, The General Accounting Office and Finality of Decisions of Government Contracting Officers, 27 N.Y.U.L. REv. 78 (1952); Cibinic \& Lasken; Foster, The General Accounting Office and Government Claims, 16 D.C.B.A.J. 193 (1949); Meyer, The Role of the Comptroller General in Awarding Formally Advertised Government Contracts, 18 AD. L. REv. 39 (Summer 1966); Welch, The General Accounting Office in Government Procurement, 14 FED. B.J. 321 (1954); Note, The Comptroller General of the United States: The Broad Power to Settle and Adjust All Claims and Accounts, 70 HARv. L. REv. 350, $357-58$ (1956).

23. All claims and demands whatever by the Government of the United States or against it, and all accounts whatever in which the Government of the United States is concerned, either as debtor or creditor, shall be settled and adjusted in the General Aecounting Office. 31 U.S.C. $\S 71$ (1970).

24. Balances certified by the General Accounting Office, upon the settlement of public accounts, shall be final and conclusive upon the Executive Branch of the Government ....

...

Disbursing officers, or the head of any executive department, or other establishment not under any of the executive departments, may apply for and the Comptroller General shall render his decisions upon any question involving a payment to be made by them or under them, which decision, when rendered, shall govern the General Accounting Office in passing upon the account containing said disbursement. Id. $\S 74$.

25. It is the province of this office in settling accounts and determining the availability of appropriations to see that contracts involving the expenditure of public funds be lcgally made, including observance of the law respecting competitive bidding; and when necessary to that end, to determine as a matter of law the meaning and effect of the terms and specifications used. 17 CoMP. GEN. 554, 557 (1938).

26. See Bid Protest Techniques 6; cf. 14 COMP. GEN. 671, 673 (1935).

27. 44 Comp. Gen. 221, 223 (1964). 
agencies since the GAO has no express statutory authority to order an agency to refrain from a proposed course of action with respect to an award. ${ }^{28}$ The courts have confirmed that the decisions of the GAO are merely advisory and do not have the legal effect of a judgment of a court. ${ }^{29}$ Practically speaking, however, the decisions of the GAO are binding upon the agency, for if the agency disregards the decision, it may face GAO's refusal to pay the contractor on the ground that the contract was awarded illegally..$^{30}$

The relief that a disappointed bidder can receive from the GAO is somewhat limited since the GAO will neither award a contract to

28. It cannot be contended that the statutes, 31 U.S.C. $\$ 71,74$ (1970), themselves grant express authority to the GAO to resolve questions pertaining to the legality of proposed or actual contract awards. Moreover, section 74 explicitly provides that only "balances" certified by the GAO shall be binding upon the executive agency. A bid protest decision is not the certification of a balance for the word "balances" presupposes a completed transaction. See Cibinic \& Lasken 377 . Section 74 also states that the Comptroller General can render advance decisions when requested by disbursing officers, or the head of any executive department, or other establishment not under any of the executive departments. Thus there is no statutory basis for a bidder on a proposed contract to request a decision of the Comptroller General. Moreover, section 74 only makes these advance decisions binding upon the Comptroller General himself. Id. Contra, Bid Protest Techniques 2.

If section 71 is read as conferring upon the Comptroller General auditing authority with respect to prospective transactions, there may be a serious separation of powers problem, since giving the Comptroller General power to control the actions of an executive agency with respect to the contracts it enters into would be an interference by a legislative officer with the duties vested in the executive braneh. See note 38 infra. See also Springer v. Philippine Islands, 277 U.S. 189 (1928).

29. The contractor can sue the United States without regard to an adverse opinion of the Comptroller General. See John Reiner \& Co. v. United States, 325 F.2d 438 (Ct. Cl. 1963), cert. denied, 377 U.S. 931 (I964); Graybar Electric Co. v. United States, 90 C. CI. 232, 244 (1940); 1 J. MCBRIDE \& I. WAChTEL, Government Contracts $\$ 7.30$ (1970). See also Wheelabrator Corp. v. Chaffee, 455 F.2d 1306, 1313, 1316 (D.C. Cir. 1971); M. Steinthal \& Co. v. Seamans, 455 F.2d 1289, 1305 (D.C. Cir. 1971); Simpson Elec. Co. v. Seamans, 317 F. Supp. 684,686 (D.D.C. 1970).

30. The fact is that, as an administrative matter, the Secretary could not pay unless the Comptroller General approved. The fact remains that the Comptroller General possessed the authority and, for a long period of time, positively asserted that he would not authorize any payments to be made to plaintiff under the contract for the articles therein called for. Graybar Elec. Co. v. United States, $90 \mathrm{Ct}$. Cl. 232, 244 (1940).

In John Reiner \& Co. v. United States, 325 F.2d 438, 442 (Ct. C1. 1963), the court rationalized that the respect paid by the executive branch to the GAO's bid protest decisions is a "means of minimizing a conflict witb another arm of the Government . . ." See also United States ex rel. Brookfield Constr. Co. v. Stewart, 234 F. Supp. 94, 100 (D.D.C. 1964). See generally Cibinic \& Lasken 377 . The GAO has stated that it has authority to disallow credit to accounts of government fiscal officers for any payments out of appropriate funds made pursuant to an illegal contract. 44 CoMP. GEN. 221, 223 (1964). 
a bidder-leaving that decision to the contracting officer ${ }^{31}$-nor award damages. ${ }^{32}$ If a bid protest is filed with the GAO before the award of the contract, ${ }^{33}$ the GAO may direct: (1) that because the procedures were violated, the procurement be cancelled and readvertised; or (2) that the procedure was proper, but that a certain bid must be rejected or a certain bid may be accepted. ${ }^{34}$ If the protest is received after the award is made, the Comptroller General will generally let the award stand although the award of the contract was improperly made.$^{35}$ Consequently, it is important that the bid protest be made promptly, otherwise the bid protestant may end up with a "moral victory only." 36

The effectiveness of the GAO remedy is also limited since the contracting officer is under no mandatory obligation to withhold an award pending GAO determination, ${ }^{37}$ and the GAO cannot require that a contract award be withheld pending its decision. ${ }^{38}$ However,

31. Cibinic \& Lasken 374; Bid Protest Techniques 3-4. However, the Comptroller General sometimes states to which bidder the contract ought to be awarded. See, e.g., 39 COMP. GEN. 282, 284-85 (1959); Bid Protest Techniques 3.

32. E.g., Unpublished Opinion, B-171612, March 19, 1971; Unpublished Opinion, B169425, June 12, 1970; Unpublished Opinion, B-168485, October 29, 1970.

33. For examples of bid protests filed with the GAO before the award of the contract, see Wheelabrator Corp. v. Chafee, 455 F.2d 1306 (D.C. Cir. 1971) (bidder claimed that the twostep formal advertising was unlawful and that the Navy was required to procure the contract by negotiation); M. Steinthal \& Co. v. Seamans, 455 F.2d 1289 (D.C. Cir. 1971) (invitation for bids cancelled because of ambiguity in delivery schedule); A.G. Schoonmaker Co. v. Resor, 445 F.2d 726 (D.C. Cir. 1971) (invitation for bids cancelled because of ambiguity).

34. See R. Nash \& J. Cibinic, Federal Procurement Law 963-64 (1969); Cibinic \& Laskin 374: Bid Protest Techniques 2-4.

35. R. NASH \& J. CiBinic, supra note 34, at 964; Bid Protest Techniques 4. The GAO usually considers the extent to which the contract has been performed, the interest of the government in having the contract completed promptly, and whether any payments have already been made under the contract. But see Unpublished Opinion, B-172570, July 26, 1971, where the GAO recommended termination for convenience of a partially completed contract (the awardee had purchased the materials for the contract, but had made no deliveries) after the low bidder had improperly been declared non-responsive.

36. Bid Protest Techniques 4.

37. I J. MCBRIDE \& I. WACHTEL, supra note 29, at $§ 7.10[4]$ (1972 Supp.). See 32 C.F.R. $\S 2.407-9(b)(2)-(3)(1971) ; 41$ C.F.R. \& 1-2.407-8(b)(3)-(4) (1972).

38. 36 Fed. Reg. 24791 (1971). The Comptroller General has no authority to direct the contracting officer to withhold award of the contract inasmuch as the GAO is a part of the legislative branch of the government. Only officials of the executive branch, namely, the head of an agency as defined in 10 U.S.C. $\S 2302$ (1970), and 41 U.S.C. $\S 249$ (1970), or persons acting under their direction, may award a contract, cancel or modify an existing one, or reject bids on a solicitation for procurement. See generally 10 U.S.C. $\S 2304$ (1970) and 41 U.S.C. $\S 252$ (1970). 
if the protest is made before the award, the procurement regulations require that the award be withheld following a written protest to the GAO unless the contracting officer makes certain findings..$^{39}$ If the contracting officer receives notice of a protest after the award, there is no requirement that the contracting officer or the contractor who received the award suspend action, ${ }^{40}$ and the GAO has no power to order suspension of the performance. ${ }^{41}$,

Another drawback of the GAO remedy is its lack of procedural safeguards. Since the bid protest procedures of the GAO do not provide for oral hearings or adjudicatory proceedings, ${ }^{42}$ its decisions are based upon the written information submitted by the bid protestant, the procuring agency, and other bidders-although an informal conference may be held with the protesting party if requested..$^{43}$ The GAO does not have an independent means of deciding disputed issues of fact; consequently, it will generally accept the agency's version of the facts ${ }^{44}$ and will not review technical judgments of the agency. ${ }^{45}$

39. The contracting officer must determine that the items to be procured are urgently required, or delivery or performance will be unduly delayed by the failure to make an award promptly, or a prompt award will not otherwise be advantageous to the government. 32 C.F.R. $\S 2.407-9(\mathrm{~b})(3)(1971) ; 41$ C.F.R. § 1-2.407-8(b)(4) (1972). The determination to make an award while the GAO decision is pending must be approved at a level higher than the contracting officer. Bid Protest Techniques 9-10. See 32 C.F.R. § 2.407-9(b)(2) (1971); 41 C.F.R. § 12.407-8(b)(3) (1972).

40. The regulations, however, advise the contracting officer to attempt to negotiate a suspension of work on a no-cost basis. 41 C.F.R. $\S$ 1-2.407-8(c) (1972); Bid Protest Teehniques 10.

41. See note 38 supra.

42. See 4 C.F.R. $\$ 20.1-3$ (1970) (bid protest procedures). See also 4 C.F.R. $\$ 20.1-.12$ (1972) (interim bid protest procedures).

43. Id. § 20.2. These regulations have recently been expanded to allow attendance at the informal conference by protestants and "other interested parties, or agency officials." 4 C.F.R. $\S 20.9$ (1972) (interim bid protest procedures); 36 Fed. Reg. 24791 (1971). See notes 186-93 infra and accompanying text.

GAO bid protests are adversary only to the extent that opposing views are contained in the written materials submitted by the parties to the protest. Moreover, the reliance of the GAO on the facts submitted by the procuring agency further weakens the adversary aspects of the proceeding. See notes $44-45$ infra and accompanying text.

44. "We have consistently held that where there are disputed questions of fact, in the absence of evidence sufficiently convincing to overcome the presumption of the correctness of the administrative report, this Office will accept the administrative report as accurately reflecting the disputed facts." 42 CoMp. GEN. 124, 134 (1962). The GAO has no provisions for discovery, formal hearings, or cross-examination of witnesses. Since all communications are ex parte, the GAO receives and relies upon unsworn statements uncontested by crossexamination. For a general discussion of the procedures for bid protests, see Bid Protest Techniques 10-14. See also 21 CoMP. GEN. 244, 249-52 (1941).

45. The Comptroller General's office does not entertain "adversary proceedings" to deter- 
Although the procedure of the GAO is not as formal or extensive as some of the bid protestants would prefer, it does enable the GAO to decide cases with relative promptness, ${ }^{46}$ and since the GAO acts predominantly upon written records, the procedure is generally less expensive than a comparable court proceeding.

A third type of relief for the bid protestant became available when the Court of Claims in Heyer Products Co. v. United States ${ }^{47}$ held that implied in every request for bids was a condition that each bid would be fairly and honestly considered. Upon this basis, the court made an exception to the Perkins holding, ${ }^{48}$ and held that an unsuccessful bidder had the right to sue for bid preparation expenses in the Court of Claims. However, the bidder could not recover loss of anticipated profits or obtain award of the contract. ${ }^{49}$ The substantive basis for recovery, moreover, was very limited-the bidder was required to show "by clear and convincing proof that there has been a fraudulent inducement for bids . . . ." No No contractor has ever recovered his bid preparation costs under the Heyer holding limiting recovery to instances of fraud or bad faith..$^{\mathbf{1 1}}$

\section{Scanwell AND ITS PROGENY}

With the foregoing overview of the remedies available to the disappointed bidder prior to February 1970, one can better understand the tremendous impact of the Scanwell decision..$^{52}$ With the exception

mine the technical merits of factual contentions between protestants and contracting officers.

$11 \mathrm{CCH}$ Cont. CAs. F. I 80,196 (1965). See also id. ๆ 80,215.

46. It takes an average of 90 calendar days between the filing of a protest with the GAO and its decision on the protest. Bid Protest Techniques 9.

47. 140 F. Supp. 409 (Ct. C1. 1956).

48. See notes 5-6 supra and accompanying text.

49. 140 F. Supp. at 413.

50. Id. at 414 .

51. The court dismissed on the merits the claim of Heyer Products Co., by finding no evidence to substantiate the contention that the government acted in bad faith, and held that the bid was properly rejected. Heyer Prod. Co. v. United States, 177 F. Supp. 251 (Ct. Cl. 1969) (on the merits). See Trans Int'l Airlines, Inc. v. United States, 351 F.2d 1001 (Ct. Cl. 1965); Green Manor Constr. Co. v. United States, 169 Ct. Cl. 413 (1965); Iscow v. United States, 161 Ct. Cl. 875 (I963); Locke v. United States, 283 F.2d 521 (Ct. C1. 1960); Keco Indus., lnc. v. United States, 149 Ct. Cl. 837 (1960), cert. denied, 365 U.S. 815 (1961).

52. At the time of this writing, however, no other circuit has decided that a disappointed bidder has standing to challenge the legality of a contract award. See Allen M. Campbell Co. v. Lloyd Wood Constr. Co., 446 F.2d 261, 264 n.5 (5th Cir. 1971); Pace Co. v. Resor, Nos. 71-1974, 71-1975 (6th Cir. 1971) (per curiam); 440 BNA FED. CoNT. REP. A-I (1972). 
of the Court of Claims, the GAO was the only tribunal outside the procuring agency itself in which an unsuccessful bidder could have a decision on the merits of his case. Yet, even the effectiveness of the GAO remedy was severely limited since the GAO had no injunctive power to suspend performance of the contract and could not actually award the contract to the unsuccessful bidder. Moreover, its informal and ex parte procedures operated more to the advantage of the government than the bid protestant regardless of how fairly the protest was treated. While the Court of Claims remedy appeared to afford some opportunity for relief, no protesting party ever recovered damages under that court's standard. Indeed, it would be a rare protestant who would feel adequately compensated by the recovery of bid preparation expenses of $\$ 100,000$, for example, when in effect he had lost a $\$ 40$ million government contract to another competitor under an illegal procurement which the GAO would not cancel because the performance of the contract had already started.

Thus, the Scanwell decision was important not only because it offered the bid protestant another independent tribunal in which to contest the illegality of the award or anticipated award of the contract, but also because it enabled the bid protestant to seek a temporary restraining order or a preliminary injunction against the procuring agency. The unsuccessful bidder could ask the court not only to reject a certain bid but also to award the contract to the protestant. Finally, the unsuccessful bidder could utilize the discovery procedures of the court and participate in an adversary proceeding with the right to cross-examine.

However, the Scanwell decision created much uncertainty concerning the exact role of the courts in the bid protest area. Gradually, in post-Scanwell decisions, the courts have answered many of the questions initially raised. In analyzing the use of the judicial forum to challenge the award or proposed award of a contract, consideration must be given to post-Scanwell developments with respect to standing, remedies, the standard of review used by the court, and the effect of the judicial remedy upon the status of the contractor who improperly received the contract award.

\section{The Standing Issue}

The court's holding in Scanwell that an unsuccessful bidder for a government contract has standing to challenge the legality of a pro- 
posed award or the award of a contract is based upon two principles. First, under section 10(a) of the Administrative Procedure Act,,$^{53}$ the unsuccessful bidder who has been aggrieved in fact has a right to assert that he was denied the contract because of the arbitrary or capricious action of the procuring agency ${ }^{54}$ Second, the unsuccessful bidder can bring the suit as a "private attorney general" to vindicate the public interest in having the agencies follow the regulations which control government contracting. ${ }^{55}$ The thrust of the decision of the court thus seems to be that a bidder need only show that he has been injured in fact in order to have standing to sue. ${ }^{56}$ Moreover, since the bidder is suing as a private attorney general, there is no need to show that he personally has a substantive legal right which has been violated.

In Ballerina Pen Co. v. Kunzig, ${ }^{57}$ the court, relying on two recent decisions of the Supreme Court, ${ }^{58}$ developed a three-part test to determine if the bidder has standing: the plaintiff must allege (1) "that the challenged action has caused him injury in fact," (2) "that the agency has acted arbitrarily, capriciously, or in the excess of statutory authority," and (3) that there is no "clear and convincing' indication of a legislative intent to withhold judicial review." ${ }^{59}$

53. A person suffering legal wrong because of agency action, or adversely affected or aggrieved by agency aetion within the meaning of a relevant statute, is entitled to judicial review thereof. 5 U.S.C. $\$ 702$ (1970).

54. 424 F.2d at 865-73.

[The bidder] should be granted the right, if possible, to make a prima facie showing that the government's agents did in fact ignore the Congressional guidelines in the manner in which they handled the granting of the contracts. If there is arbitrary or capricious action on the part of any contraeting official, who is going to complain about it, if not the party denied a contract as a result of the alleged illegal activity? Id. at 866-67.

55. Id. at 864 .

56. The court took the position that the Perkins doctrine, see notes 5-6 supra and accompanying text, had been legislatively reversed by Congress. 424 F.2d at 867 . See 3 K. DAvis, Administrative Law Treatise 220 (1958). But cf. Pierson, Standing to Seek Judicial Review of Government Contract Awards: Its Origins, Rationale and Effect on the Procurement Process, 12 B.C. IND. \& CoM. L. Rev. 1, 13-14 (1970); Leventhal, Public Contracts and Administrative Law, 52 A.B.A.J. 35, 38 (1966).

57. 433 F.2d 1204 (D.C. Cir. 1970).

58. Barlow v. Collins, 397 U.S. 159 (1970); Data Processing Serv. Org'ns, Inc. v. Camp, 397 U.S. 150 (1970). The private attorney general theory of standing, although not applicable in these cases, 397 U.S. at 153 n.l, was mentioned by the Supreme Court: "[h]e who is "likely to be financially' injured . . . may be a reliable private attorney general to litigate the issues of the public interest in the present case." Id. at 154.

59. 433 F.2d at 1207. Arguably, the third part of the test is not related to standing but rather is a jurisdictional question. 
In Blackhawk Heating \& Plumbing Co. v. Driver, ${ }^{00}$ the court discussed the important distinction between the issue of standing and the dismissal of frivolous lawsuits even though standing is found. ${ }^{61}$ The court emphasized that standing is a preliminary issue which does not go to the merits of the case. ${ }^{22} \mathrm{~A}$ bidder has standing if his mere allegations meet the three-part test set forth in Ballerina. ${ }^{63}$ On the other hand, "the mere fact that a party has standing to sue does not entitle him to render uncertain for a prolonged period of time government contracts which are vital to the functions performed by the sovereign." ${ }^{64}$ Thus, the court determined that the proper method for eliminating frivolous lawsuits in which the litigant has standing is the summary judgment proceeding..$^{65}$

One standing issue that remains unanswered is whether any unsuccessful bidder, other than the bidder who will be eligible for the award of the contract if he succeeds on the merits of the bid protest, has standing to challenge the illegality of the actions of the procuring agency. ${ }^{66}$ In all of the cases considered by the courts in the District of Columbia, the plaintiffs have been either the lowest bidder, ${ }^{67}$ the

60. 433 F.2d 1137 (D.C. Cir. 1970).

61. The court had earlier noted in Scanwell that a court must carefully control the grant of standing by the exercise of judicial discretion in order that completely frivolous lawsuits would be averted. 424 F.2d at 872 . "[I]t is of course necessary that there exist adequate safeguards to insure that there will be no incursion of frivolous lawsuits which will flood the courts with unnecessary litigation." 433 F.2d at 1209.

62. 433 F.2d at 1141 .

63. See id. at 1140 and notes $57-59$ supra and accompanying text.

64. Id. at 1141 .

65. Rather than denying access to the courts to all litigants who make claims of arbitrary or capricious agency action on the ground that there will be unmeritorious suits from time to time-a process which also has the effect of barring plaintiffs who have legitimate grievances-we have determined that considerations of standing have nothing to do with the merits of the controversy and that the summary judgment procedure contemplated by Rule 56 of the Federal Rules of Civil Procedure will serve admirably to eliminate the frivolous lawsuits which might occasionally arise. Id.

See also Wheeldin v. Wheeler, 373 U.S. 647, 649 (1963). But see Bell v. Hood, 327 U.S. 678, 682-83 (1946) (indicating exceptions to the rule).

66. Since one of the bases for granting the bidder standing in Scanwell was to protect the public interest in having the agency follow the procurement regulations and statutes, it would seem that any bidder could function as a "private attorney gencral." See note 55 supra and accompanying text. See also Projcct, Federal Administrative Law Developments-1970, 1971 DUKE L. J. 149, 276. The "private attorney general" theory has not yet been used to give any bidder standing, however, possibly because of fear of diminishing the competitiveness of the bidding system. See note 71 infra.

67. See, e.g., M. Steinthal \& Co. v. Seamans, 455 F.2d 1289 (D.C. Cir. 1971); A.G. 
next lowest bidder, ${ }^{68}$ or an incumbent contractor ${ }^{69}$ Obviously, all of these bidders could meet the "injury in fact" part of the three-part standing test. ${ }^{70}$ However, other bidders might challenge the actions of the procuring agency in the hope that the court would enjoin the agency from awarding the contract upon the results of the first solicitation and require a resolicitation of bids. This would give the bid protestant a second opportunity to submit the lowest bid. ${ }^{71}$ Any such bidder could also meet parts two and three of the test; whether he could show actual injury, however, is questionable. The courts should not grant the bidder standing unless he is able to prove that had it not been for the particular agency's failure to adhere to the procurement statute or regulation, his bid would have been the lowest responsive bid and he the lowest responsible bidder. This affords the only sound basis upon which the bidder could honestly allege he suffered injury in fact. ${ }^{72}$

\section{Types of Relief}

Money Damages. Since the district courts cannot provide monetary relief in bid protests, ${ }^{73}$ this remedy must be sought in the Court of Claims. Relying in part upon the Scanwell decision to expand its earlier ruling in Heyer, ${ }^{74}$ the Court of Claims in Keco Industries, Inc. $v$. United States $^{75}$ held that a disappointed bidder had standing to

Schoonmaker Co. v. Resor, 445 F.2d 726 (D.C. Cir. 1971); Blackhawk Heating \& Plumbing Co. v. Driver, 433 F.2d 1137 (D.C. Cir. 1970); Simpson Elec. Co. v. Seamans, 317 F. Supp. 684 (D.D.C. 1970).

68. See, e.g., Scanwell Labs., Inc. v. Shaffer, 424 F.2d 859 (D.C. Cir. 1970); Floyd F. Miner Sec. Serv., Inc. v. Paine, C.A. No. 2236-70 (D.D.C. Aug. I7, 1970).

69. See, e.g., Ballerina Pen Co. v. Kunzig, 433 F.2d 1204 (D.C. Cir. 1970); Page Communications Eng'rs, Inc. v. Resor, 15 CCH Cont. CAS. F. If 84, I54 (D.C. Cir., Dec. 4, I970).

70. See notes $57-59$ supra and accompanying text.

71. Permitting such challenges, however, might diminish the integrity and competitiveness of the bidding system, for the bidder would be acquainted with the original bids of his competitors at the time of the resolicitation. See Superior Oil Co. v. Udall, 409 F.2d 1II5, III9-20 (D.C. Cir. 1969); 10 U.S.C. $\S 2305$ (a) (I970); 32 C.F.R. $\S 2.404-I(a)$ (1971); 41 C.F.R. $\S 1-$ 2.404-1(a) (1972).

72. But see note 84 infra and accompanying text.

73. Scanwell was based in large measure on the APA, see note 53 supra and accompanying text, and the APA does not authorize monetary relief. See note 83 infra and accompanying text.

74. See notes 47-50 supra and accompanying text.

75. 428 F.2d 1233 (Ct. Cl. 1970). See also Pierson, Standing to Seek Judicial Review of Government Contract Awards: Its Origins, Rationale and Effect on the Procurement Process, 
maintain an action for money damages when the contractor made a prima facie showing that the procuring agency acted arbitrarily or capriciously. ${ }^{76}$ The court premised its decision upon two theories: one, stemming from Heyer, that when the government advertises for bids, there arises an implied contractual obligation that the government will fairly and honestly consider and evaluate each bid; ${ }^{77}$ and the other, stemming from Scanwell, ${ }^{78}$ that the bidder can act as a "private attorney general" for the benefit of the public to insure that the government enforces its regulations fairly and honestly. ${ }^{79} \mathrm{By}$ citing its precedent in Heyer, the court seems to adopt as its controlling rationale an extension of the implied contract theory to all procurement situations and not merely those involving bad faith and intentional fraud..$^{80}$ The court also states that although the private attorney general theory of Scanwell would settle the standing issue in favor of the plaintiffs, the plaintiffs could maintain the action based on the Heyer rationale even without Scanwell. ${ }^{81}$

Thus, although the court in Keco mentions Scanwell, it seems not to have based its decision upon section 10(a) of the Administrative Procedure Act as had the Scanwell court. ${ }^{22}$ Moreover, the Court of Claims probably could never grant standing on the basis of the APA since the APA does not authorize monetary relief. ${ }^{83}$ The Court of Claims continued to limit the monetary relief to bid preparation expenses and did not broaden it to include profits. ${ }^{84}$ Although the court lessened the degree of arbitrariness necessary to recover, it emphasized that the standard of proof to be applied in such cases

12 B.C. InD. \& Com. L. Rev. I, 45 (1970); Note, An Expanded Cause of Action Under the Tucker Act for an Unsuccessful Bidder. 44 TEMP. L.Q. 552 (197I).

76. 428 F.2d at 1237.

77. Id.

78. See note 55 supra and accompanying text.

79. 428 F.2d at 1238 .

80. Id. at 1237 .

81. Id.

82. See id. at $[237,1238$. See notes $53-54$ supra and accompanying text.

83. Hooper v. United States, 33I F. Supp. 1056 (D. Conn. [97I). See also 5 U.S.C. $\$ 705-$ 07 (1970). These sections of the APA provide only for voiding arbitrary and capricious agency action and do not authorize monetary relief.

84. 428 F.2d at 1240. The reason for not including profits is that no certainty exists that the plaintiffs would have been awarded the contract in any event. The government can reject all bids "if the head of the agency determines that rejection is in the public interest." I0 U.S.C. $\S 2305$ (c) (1970). 
should be a stringent one. ${ }^{85}$

In Continental Business Enterprises, Inc. v. United States, ${ }^{86}$ the latest decision by the Court of Claims concerning the recovery of bid preparation expenses, the court adopted the "reasonable basis" standard of review as promulgated by the Court of Appeals for the District of Columbia Circuit in M. Steinthal \& Co. v. Seamans. ${ }^{87}$ In order to establish that the action of the procuring agency was arbitrary and capricious, the unsuccessful bidder must prove that no reasonable basis existed for the agency's action. ${ }^{88}$ The Court of Claims noted that its decision to award money damages to unsuccessful bidders was an important alternative remedy to seeking injunctive relief in the federal district courts. ${ }^{89}$ Some persuasive considerations support this view-not only is the award of money damages less disruptive of the procurement process than the issuance of an injunction, but the Court of Claims can decide the issue of money damages "without the time pressures attendant to expedited actions for injunctive relief." 90

The question of whether any unsuccessful bidder can seek money damages in the Court of Claims, or whether that remedy is limited to a bidder who would have been awarded the contract if the procurement had been handled properly, has not yet been settled.91 The holdings in Heyer and Keco are that the implied contractual obligation is to consider each bid fairly and honestly. This suggests that the government enters into an implied contract of fair treatment with anyone who submits a bid, giving each unsuccessful bidder a cause of action to protest a bid..$^{92}$ This conclusion is also consistent with the court's position of not awarding expected profits to the bidder since the court often cannot, in fact, be assured that the plaintiff, or any

85. 428 F.2d at 1240 .

86. 452 F.2d 1016 (Ct. Cl. 1971).

87. 445 F.2d 1289 (D.C. Cir. 1971). See notes 135-37 infra and accompanying text.

88. M. Steinthal \& Co. v. Seamans, 455 F.2d 1289, 1301 (D.C. Cir. 1971); Continental Business Enterprises, Inc. v. United States, 452 F.2d 1016, 1021-22 (Ct. Cl. 1971).

89. See M. Steinthal \& Co. v. Seamans, 455 F.2d 1289, 1302, 1304 (D.C. Cir. 1971).

90. 452 F.2d at 1022 .

91. See, e.g., Continental Business Enterprises, Inc. v. United States, 452 F.2d 1016 (Ct. Cl. 1971) (plaintiff was rejected on his technical proposal without reference to the monetary part of the bid); Keco Indus., Inc. v. United States, 428 F.2d 1233 (Ct. Cl. 1970) (plaintiff was the next lowest bidder); Heyer Prods. Co. v. United States, 140 F. Supp. 409 (Ct. Cl. 1956) (plaintiff was the lowest bidder).

92. Compare this result with the one reached under the Scanwell rationale. See notes 7072 supra and accompanying text. 
bidder, would have been awarded the contract even if the government had acted fairly in handling the procurement.

Permanent Relief. Since the monetary remedy in the Court of Claims is limited to bid preparation expenses, the unsuccessful bidder is forced to seek more effective permanent relief by requesting the district court to issue a permanent injunction and order an award of the contract to the bid protestant. This is the only possible form of permanent relief which would allow the unsuccessful bidder to realize his anticipated profits on the contract.

In Simpson Electric Co. v. Seamans, ${ }^{93}$ the District Court for the District of Columbia stated that the federal courts have the power to compel the award of a contract to an unsuccessful bidder, but that the power is purely discretionary and should be sparingly used. ${ }^{94}$ In this case, the contracting officer had determined that plaintiff Simpson's bid was timely because the late submission of the bid was due solely to the mishandling of the bid by the government after its receipt. Bruno, the next lowest bidder, protested the decision to the Comptroller General who decided in favor of Bruno. Subsequently, the contracting officer "bowed to the practicalities and awarded the contract to Bruno." 95 Simpson then brought an action in the federal district court to enjoin the award of the contract to Bruno and to compel the award to himself. Although the court agreed that grant of the award to Bruno was illegal and that the contract should have been awarded to Simpson, it refused to grant any injunctive relief, stating that " $[\mathrm{m}]$ andatory relief by way of injunction is not required to preserve the integrity of the bid process since a declaration of rights with the liability of damages that will flow therefrom will suffice." ${ }^{96}$ The court distinguished Superior Oil Co. v. Udall ${ }^{87}$-where the court of appeals compelled the Secretary of the Interior to issue

93. 317 F. Supp. 684 (D.D.C. 1970).

94. Id. at 688.

95. Id. at 685 .

96. Id. at 688 .

97. 409 F.2d 1115 (1969). Superior Oil Co., predating Scanwell by one year, involved the sale by the government of an oil lease rather than a government procurement. Here the court ordered that the oil lease be issued to Superior Oil since the highest bidder, Union Oil, had failed to properly sign its bid. It is possible to distinguish this case from others where an order is sought compelling award since the Superior Oil court ruled that a contract came into being as a result of the government's holding of the Superior check that accompanied its bid. In inost cases an actual acceptance will not have taken place. 
a lease to a bidder whom the lower court had held to be entitled to the contract-in that Superior Oil Co. involved a long-term performance contract worth millions of dollars that had not yet been awarded, whereas the contract in Simpson Electric was a short-term military supply contract where performance had already begun. This distinction indicates that the court will consider the length of the contract, the amount of money involved, and whether performance of the contract has already started in determining whether to compel the award of the contract to the unsuccessful bidder ${ }^{98}$ Thus, Simpson underscores the importance of seeking relief promptly, especially where a short-term contract is involved.

Despite the large number of cases brought in the district courts since Scanwell, contracts have been awarded to the unsuccessful bidder in only two cases, one of which was reversed on appeal. In BlountBarfell-Dennehy, Inc. v. United States, ${ }^{99}$ a low bidder on a Veterans Administration construction contract submitted a bid bond naming as principal a joint venture of which the bidder was a member, while the bid itself was in the name of the bidder. The Veterans Administration submitted the matter to the GAO, which subsequently ruled that the bid bond was not acceptable and therefore the low bid could not be accepted. ${ }^{100}$ The low bidder then filed for a temporary restraining order in district court. Subsequently, the surety tendered a new bond naming only the bidder as principal. The Veterans Administration's attorney then indicated to the court its willingness to do business with

98. Compare the Simpson decision with GAO decisions which let an award stand, although the award of the contract was improperly made, if the protest is received after the award is made. See notes 35-36 supra and accompanying text. See also Lombard Corp. v. Resor, 321 F. Supp. 687 (D.D.C. 1970), which involved the rejection of the proposal of a prime contractor submitted by a would-be subcontractor where the contracting officer had the right to approve subcontractors. The subcontractor then filed a bid protest with the GAO which was denied. Unpublished Opinion, B-166532, April 7, 1970. He then filed in the District Court for the District of Columbia, where relief was also denied. It is significant, however, that while the decision was pending, heavy expenses were incurred under the contract- $\$ 1,500,000$ was allegedly expended or contracted for. The court took a dim view of the rush to spend money prior to a bid protest ruling, since the GAO will not usually vacate an award where performance has already started: "[w]hile it is obvious that an agency or contractor cannot afford to stop all action every time a disappointed bidder files for relief, it should be noted that in a case in which the court felt there was arbitrary action in the award of a contract, we would not hesitate to enjoin further payment by the Government, letting the chips fall where they may." 321 F. Supp. at 693.

99. Civil No. 70-392 (W.D. Okla., Aug. 6, 1970).

100. Unpublished Opinion B-170361, July 27, 1970. 
the low bidder since the bid bond was reformed. ${ }^{101}$ The court apparently acquiesced in this agreement and entered a judgment granting the contract to the lowest bidder. Although the court did direct the award of the contract, the decision is of doubtful precedential value since, in fact, the court did little more than accommodate the willingness of the Veterans Administration to award the contract to the low bidder.

In A.G. Schoonmaker Co. v. Resor, ${ }^{102}$ a federal district court prohibited the Department of Defense from opening any bids received upon a resolicitation, and required the Department to make an award to Schoonmaker on the basis of its bid in the initial solicitation. Schoonmaker, the low bidder in an Army solicitation for generators, submitted higher prices for its preproduction than for its production models. The next lowest bidder then protested to the GAO on the ground that the invitation for bids required identical prices for both models. The Comptroller General, while acknowledging that Schoonmaker's bid was responsive to the invitation for bids, nevertheless found that the invitation for bids was ambiguous and ordered that all bids be rejected and new bids solicited. ${ }^{103}$ The Army proceeded to resolicit bids, whereupon Schoonmaker obtained a permanent injunction in district court directing award of the contract to Schoonmaker upon its initial bid. On appeal, the Court of Appeals for the District of Columbia Circuit reversed the district court and stated that the Comptroller General had decided that the invitation for bids was ambiguous and that the Army, therefore, did not act arbitrarily or capriciously in following the GAO's opinion. ${ }^{104}$

It should be noted that the reversal by the court of appeals was not based on a lack of power in the court to direct the award of a contract, but rather on a finding that the Army had not acted arbitrarily or capriciously in deciding that the invitation for bids was ambiguous. This seems to leave intact the holding of the district court in Simpson that the courts have the discretionary power to award the

101. 367 BNA FED. CoNt. REP. A-5, A-7 (1971).

102. Civil No. $1760-70$ (D.D.C., preliminary injunction granted June 26, 1970; permanent injunction granted Sept. 24, 1970), rev'd and remanded with direction to dismiss the complaint, Nos. 24706, 24708 (D.C. Cir., March 5, 1971), modified on rehearing, 445 F.2d 726 (D.C. Cir. 1971).

103. Unpublished Opinion, B-169205, May 22, 1970, affd on reconsideration, June 23, 1970.

104. 445 F.2d 726 (D.C. Cir. 1971). 
contract itself, although no court of appeals has specifically ruled on the matter ${ }^{105}$ This is a significant remedy since the GAO will not award a contract. ${ }^{106}$

Temporary Relief. The recent decision of the Court of Appeals for the District of Columbia Circuit, in Wheelabrator Corp. $v$. Chaffee, ${ }^{107}$ established that an important function to be performed by the district courts in the adjudication of government contracts disputes is that of issuing preliminary injunctions to restrain government action pending a GAO decision. In the opinion of the court, use of the preliminary injunction serves a dual purpose: first, the issuance of the preliminary injunction will necessarily maintain the status quo and thus prevent either the awarding of a contract or the performance of a contract already awarded while the GAO decision is pending; second, the court can gain the benefit of the GAO's expertise before making a decision on the merits. ${ }^{108}$ Since the opinions of the GAO are advisory only and not binding on the parties, ${ }^{109}$ the fact that a district court issued an injunction to await a GAO decision was an unusual development. ${ }^{110}$ The court, however, was of the opinion that the GAO has greater experience and expertise than the district court in the field of procurement law and that the court would, therefore, benefit from the decision of the agency. ${ }^{111}$ The court discussed at great length the importance of the GAO in the field of government procurement, ${ }^{112}$ and upon this basis applied the doctrine of primary jurisdiction to the GAO:

This doctrine has application to the GAO even assuming that its function is

105. But see Scanwell Labs., Inc. v. Shaffer, 424 F.2d 959, 964 (D.C. Cir. 1970).

Mr. Paul Dembling, General Counsel, GAO, has raised the interesting question of the result, assuming the district court ordered the procuring agency to award the contract to Bidder $X$, if five minutes after the agency makes the award to Bidder $X$, the contracting officer terminates the contract for convenienee pursuant to the appropriate clause. Judicial and GAO Review of Bid Protest Cases 7. See notes 155-58 infra and accompanying text.

106. See note 31 supra and accompanying text.

107. 445 F.2d 1306 (D.C. Cir. 1971).

108. Id. at 1316.

109. See notes 28-29 supra and accompanying text.

110. Indeed, the court in Scanwell indicated that an unsuccessful bidder need not obtain a determination by the GAO before filing suit in the district court: " $[t]$ the district court will have the benefit of the record upon which the Comptroller General would rely. No additional findings of fact would be made and no hearings would be held; there would therefore be no additional groundwork laid for the court to review." 424 F.2d at 876.

111. 455 F.2d at 1316.

112. Id. at 1313-16. 
advisory since it has the special competence and experience that is the life and reason of the primary jurisdiction rule. ${ }^{113}$

Whether a preliminary injunction should be granted pendente lite is interrelated with the question whether the doctrine of primary jurisdiction should be invoked, but the two issues involve questions to be determined separately by the court. ${ }^{114}$ According to the court, an injunction should not be issued as a matter of course, pursuant to the doctrine of primary jurisdiction, merely because a decision is pending before the GAO or will be brought before the GAO; rather, the plaintiff must still meet the standards required for issuance of a preliminary injunction in other types of litigation. Thus, the plaintiff must show that he is likely to prevail on the merits, that without the relief requested he will be irreparably injured, that the injunctive relief will not cause substantial harm to the other parties interested in the proceedings, and that such relief is in the public interest. ${ }^{115}$ The court in Wheelabrator specifically emphasized that a "preliminary injunction cannot be justified unless the court makes a considered judgment of the probability of success on the merits." 116 However, the court did indicate that an analysis of these issues need not be as comprehensive "when ... [the] injunction is limited to the period required for a determination by the GAO in the protest," 117 thereby alleviating some of the pressures involved in making very technical judgments on an expedited basis. ${ }^{118}$

The procedure endorsed in Wheelabrator was actually utilized

113. Id. at 1316. The authoritative statement of the doctrine of primary jurisdiction appears in United States v. Western Pac. R.R., 352 U.S. 59 (1956):

"Primary jurisdiction". . a applies where a claim is originally cognizable in the courts, and comes into play whenever enforcement of the claim requires the resolution of issues which, under a regulatory scheme, have bcen placed within the spccial compctence of an administrative body; in such a case the judicial process is suspended pending referral of such issues to the administrative body for its views. Id. at 63-64.

See generally 3 K. Davis, Administrative Law Treatise $\$$ 19.01 -.09 (1958).

114. 455 F.2d at 1317.

115. Virginia Petroleum Jobbers Ass'n v. FPC, 259 F.2d 921, 925 (D.C. Cir. 1958). See Wheelabrator Corp. v. Chafee, 455 F.2d 1306, 1317 (D.C. Cir. 1971).

116. 455 F.2d at 1317.

117. Id.

118. Since Wheelabrator was decided, the District Court for the District of Columbia has followed this procedure in General Elec. Co. v. Seamans, 340 F. Supp. 636 (D.D.C. 1972). The court granted an injunction during the pendency of a bid protest with the GAO on the basis that the protestant was likely to succeed on the merits before the GAO and ultimatcly in court, and further, because there existed no adequate remedy at law. 
prior to that decision in Page Communications Engineers, Inc. $v$. Resor. ${ }^{119}$ In Page, an incumbent contractor filed a protest with the GAO and a suit for injunctive relief with the district court, after the Army awarded a contract for operation of its communications system in South Vietnam to another bidder. The court granted the preliminary injunction for forty-five days or until the Comptroller General had rendered its decision on the protest, whichever was earlier. The Court of Appeals for the District of Columbia Circuit reversed the decision on the narrow ground that the district court had made no finding of the plaintiff's likelihood of success on the merits and had not expressly considered the public interest in unimpeded implementation of military programs and in the speedy replacement of Army personnel in Vietnam. ${ }^{120}$ The court did note with approval, however, that the lower court had taken into account the GAO protest and the need to assure the integrity of that proceeding. ${ }^{121}$

The use of the preliminary injunction in combination with the GAO remedy should not only be useful to the plaintiff but should also aid the courts in reaching correct results. Although many of the preliminary injunctions issued in the District of Columbia by the district court subsequent to Scanwell have been overturned by the court of appeals, very few of the decisions by the court of appeals have been inconsistent ${ }^{122}$ with the determinations of the GAO. This perhaps corroborates the efficacy of awaiting a GAO determina-

119. Civil No. 3173-70 (D.D.C., Nov. 3, 1970).

120. 15 CCH Cont. CAS. F. If 84,154 (D.C. Cir., Dec. 4, 1970).

121. [T] he District Court properly took into account the protest proceeding and any possible need to assure its integrity. As the Court indicated, the Comptroller General's decision might conceivably dispose of the controversy. At the very least, it should provide the court with additional guidance in resolving the issues before it. Id.

The court stayed its order for 15 days to allow the plaintiff to seek further injunctive relief. The GAO decision, which came just three days prior to the expiration of the stay, denied Page's protest. Unpublished Opinion, B-171076, Dec. 16, 1970. The district court then refused to reinstate the preliminary injunction, finding that there was no substantial question regarding the legality of the award and that there was no substantial likelihood that Page would prevail on the merits. The government then filed a counterclaim for damages on the bond in an unspecified amount. The latter case is pending on the merits in the district court. 357 BNA FED. Cont. Rep. A-13, A-14, A-16 (1971); Judicial and GAO Review of Bid Protest Cases 14.

122. E.g., Wheelabrator Corp. v. Chafee, 455 F.2d 1306 (D.C. Cir. 1971); M. Steinthal \& Co. v. Seamans, 455 F.2d 1289 (D.C. Cir. 1971); Page Communications Eng'rs., Inc. v. Resor, 15 CCH Cont. CAS. F. II 84,154 (D.C. Cir., Dec. 4, 1970). 
tion. ${ }^{23}$ In any event, the use of the preliminary injunction pending GAO decisions may obviate some of the criticism leveled at the GAO-that its decisions, in practice, come too late to give adequate relief to the plaintiff. ${ }^{124}$

An important facet of obtaining a preliminary injunction is the requirement that the plaintiff file rather large bonds pending the outcome of the case. ${ }^{125}$ The bonds are to cover the costs and damages suffered by any party ultimately decided to have been wrongfully enjoined. The largest bond required thus far has been $\$ 100,000$, in Page. ${ }^{126}$ However, the threat of massive liability was reduced when the district court ruled that, absent proof of malice in initiating the suit, the bid protestant's liability is limited to the maximum amount of the bond. ${ }^{127}$

\section{Standard of Review}

It should be emphasized at this point that it is always the decision of the procuring agency which is reviewed by the court, even though the GAO may also have rendered a decision on the bid protest. This is of particular importance in light of the Wheelabrator holding that the court under the doctrine of primary jurisdiction should defer to the expertise of the GAO. ${ }^{128}$ In Simpson the district court carefully pointed out that it was the action of the contracting officer rather than that of the GAO which was under consideration, since it is the decision of the officer that is final within the meaning of the Administrative Procedure Act. ${ }^{129}$ However, some confusion later arose in Schoonmaker over this distinction. In the first opinion written by the court of appeals in Schoonmaker, it found that the GAO had not acted arbitrarily or capriciously. ${ }^{130}$ The court later modified its opin-

123. See notes 202-09 infra and accompanying text.

124. See notes 35-36 supra and accompanying text.

125. See 7 J. Moore, Federal Practice $§ 65.10$ [1] at 1657 (1971).

126. 352 BNA Fed. Cont. Rep. A-9, A-10 (1970).

127. 380 BNA FED. CONT. ReP. A-3 (1971). There are still open questions concerning what types of damages, e.g., increased production costs, can be recovered against the bond.

128. See notes $111-13$ supra and accompanying text.

129. 317 F. Supp. at 686 . See notes $93-96$ supra and accompanying text.

130. Regardless of the manner in which we would interpret the invitation, we cannot find that different people might not read it differently or that the Comptroller was either arbitrary or capricious in deciding that it was ambiguous and did not provide clear and objective instructions to the bidders. Nos. 24,706, 24,708, at 5 (D.C. Cir., March 5, 1971). 
ion, emphasizing that the decision of the procuring agency was under review, and that the decision of the Comptroller General is important only to the extent that it is relied upon by the procuring agency. ${ }^{131}$

In M. Steinthal \& Co. v. Seamans, ${ }^{132}$ the Court of Appeals for the District of Columbia outlined for the first time the standard that the district court should apply in reviewing agency procurement decisions. The court noted that its earlier suggestions were made with a view toward limiting the role of the courts in order to avoid disrupting the procurement process. ${ }^{133}$ It also recognized the difficulties inherent in dealing expeditiously with technical issues that arise in connection with complex regulations and contract specifications. ${ }^{134}$ With these considerations in mind, the court laid down the following standard of review for procurement actions:

(1) courts should not overturn any procurement determination unless the aggrieved bidder demonstrates that there was no rational basis for the agency's decision; and (2) even in instances where such a determination is made, there is room for sound judicial discretion, in the presence of overriding public interest considerations, to refuse to entertain declaratory or injunctive actions in a pre-procurement context. ${ }^{135}$

In support of the first part of the test, the court stressed that it was obligated to "restrict its inquiry to a determination of whether the decision of the procurement agency had a reasonable basis," 136

131. We recognize that in this case the Comptroller's opinion differed from that initially taken by the Army. Whether the Army was convinced by the Comptroller's reasoning or acceded to it to avoid a conflict, the Army's final action should not be set aside. If the Army did finally adopt the Comptroller's opinion as its own then its action is not arbitrary or capricious unless the opinion upon which it was based was arbitrary or capricious. If on the other hand the Army simply acceded to the opinion of the Comptroller to avoid a conflict, still its act is not arbitrary or capricious. An accession by a contracting officer to the General Accounting Office, at least where the opinion as to which the accession is made is itself reasonable, may be in the public interest if for no other reason than that it eliminates the insufferable uncertainties faced by all parties where there is conflict between the General Accounting Office and a procuring agency. 445 F.2d at 728 .

132. 455 F.2d 1289 (D.C. Cir. 1971).

133. Id. at 1300 . For the court's views on limiting judicial interference in the procurement process, see A.G. Schoonmaker Co. v. Resor, 445 F.2d 726, 728 (D.C. Cir. 1971); Page Communications Eng'rs, Inc. v. Resor, $15 \mathrm{CCH}$ Cont. CAs. F. If 84, 154 (D.C. Cir. 1970); Blackhawk Heating \& Plumbing Co. v. Driver, 433 F.2d 1137, 114 I (D.C. Cir. 1970).

134. 455 F.2d at 1301. See also Continental Business Enterprises, Inc. v. United States, 452 F.2d 1016, 1022 (Ct. C1. 1971).

135. 455 F.2d at $\mathrm{t} 30 \mathrm{l}$.

136. Id. For a general discussion of the "reasonable basis" standard of judicial review, see 4 K. Davis, Administrative Law Treatise $§ 30.05$ (1958). 
even though the court itself, in the first instance, might have reached a different conclusion. This standard was deemed necessary in order to give proper deference to the discretion of procuring officials in applying the highly technical regulations and statutes that often apply to individual procurements. ${ }^{137}$

The second standard to be applied reflects the court's view that, even though no rational basis is found, an injunction may be denied because of "overriding public interest considerations"-for example, important short-term procurements which the government needs to fill as expeditiously as possible. ${ }^{138}$ Because of the availability of a remedy for damages in the Court of Claims, the District of Columbia Circuit believes that the denial of an injunction in these instances would not be inequitable to the frustrated bidder. ${ }^{139}$

The opinion in Steinthal clearly emphasizes the heavy burden that will be placed upon any plaintiff seeking reversal of determinations made by procurement officials and indicates that the court will not tolerate any frivolous lawsuits, ${ }^{140}$ cautioning that "[o]nly when the court concludes that there has been a clear violation of duty by the procurement officials should it intervene in the procurement process and proceed to a determination of the controversy on the merits."

In enunciating these standards, the court justifies its restraint by pointing out the availability of remedies through the Court of Claims and the GAO. ${ }^{142}$ While the court reiterated its deference to the GAO as an expert in handling bid protest cases, ${ }^{143}$ it carefully pointed out that it will not recede from its position in Scanwell that bidders who act as "private attorney generals" are furthering the public interest

137. 455 F.2d at $1301-02 \&$ n. 40 .

138. Id. at $1302 \&$ n.4I.

139. Id. at 1302. The court does point out that the damage remedy in the Court of Claims cannot be considered adequate since there is no recovery for lost profits. The court would, therefore, limit the denial of an injunction in which the public interest considerations are particularly important.

140. Id. at 1303. See notes 60-65 supra and accompanying text.

141. Id. at 1303 (emphasis added). The court indicated that the official duty violated must be a ministerial duty not involving room for discretion. Apparently excluded from the court's admonition are gross abuses of discretion.

142. Id. at I302. The court also observed that the real importance of Scanwell was probably not the small number of cases that might result in judicial intervention; rather, it was the greater number of cases that would now be handled more carefully within the government because of the awareness of the availability of judicial scrutiny. Id. at 1301.

143. Id. at 1304-05. See notes 111-13 supra and accompanying text. 
and the integrity of the procurement process. ${ }^{144}$ Yet, this public interest must be balanced against the public's interest in a smooth-running and expeditious procurement process. According to Steinthal, this balance can best be attained by the "rational basis" standard of judicial review. ${ }^{145}$

\section{Status of Contractor Where Award to Him Is Held IMPROPER}

What is the status of the contractor who is awarded a contract by the procuring agency when the court subsequently holds that the award to him is improper? If the court so holding refuses, in the exercise of its discretion, to enjoin his performance of the contract, ${ }^{146}$ could the procuring agency, nevertheless, then rescind the contract as void $a b$ initio or terminate the contract for convenience? ${ }^{147}$ On the other hand, if the court does cancel the award and compels the award of the contract to another bidder, does the original awardee have any right to recover damages other than a possible recovery of bid preparation expenses in the Court of Claims? ${ }^{148}$ These questions have not yet been decided, but some helpful analogies may be drawn from the

144. Id. at 1305. See notes 55-56 supra and accompanying text.

145. Compare the "rational basis" standard with the GAO standard of review in note 27 supra and accompanying text. See also John Reiner \& Co. v. United States, 325 F.2d 438, 440 (Ct. Cl. 1963).

146. These are basically the facts of Simpson Elec. Co. v. Seamans, 317 F. Supp. 684 (D.D.C. 1970). See notes 93-98 supra and accompanying text.

147. The termination for convenience clause is included, either expressly or impliedly, in every contract awarded by the federal government. It provides that the performance of work under any contract may be terminated by the government whenever the contracting officer determines that termination is in the best interests of the government. The concept of termination for convenience of the government was developed in order to protect the government against acceptance of obsolete or excess materials prior to the time a contract is eompleted. See 32 C.F.R. pt. 8 (1971); 4 I C.F.R. pt. $1-8$ (1972); 4 J. MCBRIDE \& I. WACHTEL, GoverNMENT CONTRACTS, $\S 30.10[1](1969)$. The termination clause defines the rights of the government and of the contractor and provides a format for the settlement of claims. 41 C.F.R. $§ \S 1-$ 8.700 to 8.806 (1971) contains the clauses and forms related to the termination of contracts.

148. In Lloyd Wood Constr. Co. v. Sandoval, 318 F. Supp. 1167 (N.D. Ala. 1970), the district court ruled that the low bidder could not receive the contract, but the court did not direct the award to the plaintiff, the next lowest bidder. Nonetheless, pursuant to the decision, the agency cancellcd the contract with the low bidder and awarded it to the next lowest bidder. Performance of the contract by the next lowest bidder was substantially complete when the Court of Appeals for the Fifth Circuit, 446 F.2d 261 (5th Cir. 1971), reversed the decision of the district court and held that the initial award of the contract had been correct. The low bidder is now suing the government in the Court of Claims for $\$ 500,000$ for breach of contract. Judicial and GAO Review of Bid Protest Cases 9. 
decisions of the Court of Claims.

The Court of Claims has not held that every contract improperly awarded is automatically void ab initio. Rather, in Prestex Inc. v. United States, ${ }^{199}$ the court stated that the government may disclaim a contract as void $a b$ initio only when there exists a bid deviation which affects the substance of the bid or works as an injustice on other bidders. ${ }^{150}$ It appears, however, that in most cases in which the district court would find a contract award improper under the Steinthal standard, the contract would also be void ab initio under the standard of the Court of Claims inasmuch as a substantial deviation is defined as one which affects either the price, quantity, or quality of items specified in the contract. ${ }^{151}$ If such a deviation is ignored by the contracting officer, he would be clearly violating his duty, under the procurement statutes and regulations, to accept bids which comply with the invitation. ${ }^{152}$ If the illegality of the contract is so plain that the contract is void $a b$ initio, the government could then properly rescind the contract, and the contractor would be denied all recovery. ${ }^{153}$ In addition, under the doctrine of quantum meruit, the contractor could receive reimbursement only for expenses which tangibly benefited the government. ${ }^{154}$ Consequently, if a district court holds that a contract award is improper but does not issue an injunction, the procuring agency may, nevertheless, rescind the contract as void $a b$ initio; such a rescission would not increase the government's liability for damages if the impropriety of the award falls within the Prestex standard.

Whenever a court holds that the contract is improperly awarded-even if the contract is not void ab initio-the procuring agency could properly terminate the contract under the termination for convenience provisions ${ }^{155}$ and not be liable for breach of contract. ${ }^{156}$ In this situation the recovery of the contractor would be

149. 320 F.2d 367 (Ct. Cl. 1963).

150. Id. at 372.

151. Id.

152. See id. at 371-72. See note 140 supra and accompanying text; 10 U.S.C. $\$ 2305$ (c) (1970); 41 U.S.C. $\$ 253$ (b) (1970); 32 C.F.R. \$ 2.404-2 (1971); 41 C.F.R. $\$ 1-2.404-2$ (1972).

153. John Reiner \& Co. v. United States, 325 F.2d 438, 440 (Ct. Cl. 1963); 320 F.2d at 373.

154. 325 F.2d at $440 ; 320$ F.2d at 373.

155. Albano Cleaners, Inc. v. United States, No. 188-67 (Rep't of the Comm'r to the Ct. Cl., Oct. 7, 1971, at 8). See note 147 supra.

156. G.C. Casebolt Co. v. United States, 42I F.2d 710 (Ct. Cl. 1970). This is consistent 
determined by the formula specified in the termination clause. That formula precludes recovery for lost profits but would cover any expenses incurred..$^{157}$ If the government does not cancel the contract through the termination clause, and instead incorrectly treats it as a contract void $a b$ initio, the contractor may sue for damages in the Court of Claims, and if successful, his recovery will be measured by the termination for convenience clause. ${ }^{158}$

\section{CHOICE OF Forum}

Because many of the basic issues concerning the role of the judiciary in procurement controversies have been settled by recent decisions of the Court of Appeals for the District of Columbia, it is now possible for the unsuccessful bidder to compare with more certainty the availability and effectiveness of relief in the federal district courts with that afforded by the GAO and the Court of Claims. This comparison is important in order to determine what forum or combination of forums will give the unsuccessful bidder the best possibility for obtaining relief. The following discussion examines and evaluates the possible choices. It assumes that the prospective litigant would first bring suit in the federal district court or the GAO before going to the Court of Claims, since the Court of Claims' remedy is limited to recovery of bid preparation expenses. ${ }^{159}$ The discussion is structured around the following example: Bidder $X$ was the second lowest bidder responding to an advertised bid for a government contract. $Y$ was the low bidder. Shortly before the contract is to be awarded, $X$ learns that the contracting officer will make the award to Bidder $Y$. $X$ wants to challenge the legality of this decision on the ground that the bid of $Y$ was not responsive to the invitation for bids. ${ }^{160}$

with the rulings of the Court of Claims that it can be considered in the government's best interest to use the termination for convenience clause to avoid conflicts with the GAO and with Congress. Id. at 712-13.

157. Id. at 713; Nesbitt v. United States, 345 F.2d 583, 586 (Ct. Cl. 1965), cert. denied, 383 U.S. 926 (1966); Brown \& Son Elec. Co. v. United States, 325 F.2d 446, 450 (Ct. C1. 1963). 158. Albano Cleaners, Inc. v. United States No. 188-67 (Rep't of the Comm'r to the Ct. Cl., Oct. 7, 1971, at 7-8).

159. Sce note 84 supra and accompanying text.

160. See 32 C.F.R. $\$ 2.301$ (1971) (armed services procurement bids must be responsive); 41 C.F.R. $\$ 1-2.301$ (1972) (other federal procurement bids must be responsive). This hypothetical assumes that protest to the contracting officer was unavailing. 


\section{Bid Protest Is Filed First with the GAO}

$X$ files a protest with the GAO without simultaneously bringing suit in the district court. ${ }^{161}$ If the GAO finds that the bid of $Y$ was unresponsive, it may issue a decision which prohibits the contracting officer from making the award. In addition, the decision might also indicate that $X$ is eligible for the award, but it will not specify that an award must be made to $X$. The contracting officer will then comply with the GAO decision by not awarding the contract to $Y$. In addition, he will either award the contract in his own discretion to $X$, cancel the procurement, or resolicit the bid. Consequently, the only immediate effect of the protest filed by $X$ is that no award can be made to $Y$ and that the award may be made to $X$. However, since the decisions of the GAO are not legally binding, ${ }^{162} Y$ may file a suit in a federal district court to enjoin the contracting officer from awarding the contract to $X$ or resoliciting bids, and to compel award of the contract to himself as the lowest responsive bidder.

Likewise, if in the first instance, $X$ loses his bid protest before the GAO, he can still seek relief in federal district court since the decisions of the GAO are no more binding upon the court than they are upon the bidder. ${ }^{163}$ However, the Court of Appeals for the District of Columbia has instructed the district courts to give due consideration to the decisions of the GAO, especially where the GAO has agreed with the contracting officer. ${ }^{164}$ Although the decisions by the

161. See notes 31-34 supra and accompanying text. The latest bid protest procedures issued by the GAO impose a very short time limitation for filing bid protests. 36 Fed. Reg. 24791 (1971). If the protest is based upon alleged improprieties which are apparent prior to the opening of bids or the closing date for receipt of proposals, the protest must be filed prior to the bid opening or closing date. In all other cases, the protest must be filed not later than five days after the basis for the protest is known or should have been known. The Comptroller General, in his discretion, may hear cases which are not filed timely if good cause is shown or if the Comptroller General determines that a protest raises significant issues. 4 C.F.R. $\$ 20.2$ (1972).

It might be argued that technically the ten year statute of limitations, 31 U.S.C. $\$ 71$ a (1970), applies to bid protests in the GAO since the GAO bases its authority to decide bid protests upon 31 U.S.C. $\$ 71$ (1970). See note 23 supra and accompanying text.

Since a decision by the GAO on a bid protest is not a prerequisite to a suit in the district court, a bid protest filed with the GAO does not toll the running of the statute of limitations in the district court. See Iran Nat'l Airlines v. United States, 360 F.2d 640 (Ct. C1. 1966).

162. See notes 28-29 supra and accompanying text.

163. Wheelabrator Corp. v. Chafee, 455 F.2d 1306, 1316 (D.C. Cir. 1971).

164. "A court's reluctance to interfere with the executive procurement process should be especially strong where . . . the General Accounting Office has made a determination uphold- 
GAO are not dispositive, ${ }^{165}$ the deference that the courts are now required to show to the GAO's decisions implies that the bid protestant will have a heavy burden to overcome when the GAO has in fact ruled against him and agreed with the contracting officer.

Thus, on the one hand, even if $X$ initially wins before the GAO, he may eventually lose if $Y$ brings suit in the district court-though admittedly, $Y$ would face the burden of overcoming the court's deference to the GAO's decisions. On the other hand, if $X$ loses in the GAO, the court's deference to the GAO could also make it harder for $X$ to win in the district court than if he had filed there prior to going to the GAO. There are also related problems in filing first with the GAO which may affect the availability of remedies for $X .^{166}$ Not only is the GAO unable to award the contract to $X$, but also it lacks power to maintain the status quo and thereby prevent an award to $Y$ while the case is pending before the GAO. ${ }^{167}$ When in fact the circumstances are such as to allow the contracting officer to award the contract, ${ }^{168} X$ may end up with a mere moral victory if the GAO decides it is in the best interests of the government not to cancel the contract. ${ }^{169}$ Moreover, if the suit is subsequently brought in court and performance has already begun on the contract, the court may, in its discretion, allow the award to stand. Despite these drawbacks, the

ing the procurement officials on the merits." M. Steinthal \& Co. v. Seamans, 455 F.2d 1289, 1304 (D.C. Cir. 1971). Compare A.G. Schoonmaker Co. v. Resor, 445 F.2d 726, 728 (D.C. Cir. 1971) (where the court of appeals noted that the district court failed to examine the findings of the Comptroller General and admonished the lower court to consider those findings in the future) with Page Communications Eng'rs., Inc. v. Resor, 15 CCH CoNT. CAS. F. If 84,154 (D.C. Cir., Dec. 4, 1970) (where the court of appeals noted that the district court properly took into account the protest proceeding with the GAO).

165. M. Steinthal \& Co. v. Seamans, 455 F.2d 1289, 1305 (D.C. Cir. 1971).

166. For example, if the solicitation were a contract set-aside under the Small Business Act, 15 U.S.C. $\S 631$ et seq. (1970), $X$ might allege that $Y$ was not eligible since he did not qualify as a small business. See 32 C.F.R. $\S 1.703$ (1971); 41 C.F.R. $\S 1.703$ (1972). However, the GAO will accept SBA determinations on size, capacity, and set-aside policies unless there is some indication of fraud or bad faith. Judicial and GAO Review of Bid Protest Cases 9. See notes 199-201 infra and accompanying text.

167. See notes $37-41$ supra and accompanying text.

168. See 32 C.F.R. ch. $1, \S 2-407-9$ (b)(3) (1971); 41 C.F.R. $\S 1-2.407-8(b)(4)$ (1972).

169. See note 35 supra and accompanying text. Thus, expediency in bringing the case before the GAO is very important. If the facts in the example were changed slightly so that the contracting officer had awarded the contract before $X$ filed a protest with the GAO, the GAO would most likely not cancel the contract even if the bid of $Y$ was unresponsive. If the district court then heard the case, it might also leave the bidder to his damage remedy in the Court of Claims. Simpson Elec. Co. v. Seamans, 317 F. Supp. 684, 688 (D.D.C. 1970). 
bidder may find the GAO more advantageous because its proceeding is more informal and thus less expensive, and its standard of review is more flexible than the standard applied by the courts. ${ }^{170}$

\section{Bid Protest Is Filed First with the District Court}

$X$ may first file a suit in the federal district court without simultaneously filing a protest with the GAO.${ }^{171} X$ should name the procuring agency and $Y$ as parties to the action in order to bind both of these parties if the court should reach a decision on the merits. In that way no party could then file a bid protest with the GAO, because the decision of the court would be res judicata. ${ }^{172}$ However, the court of appeals stated, in Wheelabrator, that the doctrine of primary jurisdiction has application to the GAO. Consequently, the court may insist that $X$ file a protest with the GAO before the court will decide the case on the merits. ${ }^{173}$ Because the District of Columbia Circuit has encouraged this procedure, it is now very likely that even though $X$

170. See note 46 supra and accompanying text. Compare John Reiner \& Co. v. United States, 325 F.2d 438, 440 (Ct. Cl. 1963) (Comptroller General can render awards invalid that would be held valid in court) with 44 COMP. GEN. 221, 223 (1964) ("We will advise . . . that credit will not be allowed only when we are convinced that the agency has awarded a contract under procurement standards which a court would find so incompatible with governing statutes and regulations as to render such contract a nullity.").

171. The Court of Appeals for the District of Columbia has recognized that the bid protest procedure is an optional remedy which does not have to be exhausted before going to the court. Scanwell Labs., Inc. v. Shaffer, 424 F.2d 859, 875 (D.C. Cir. 1970).

Tcchnically, the limitations period for bringing a suit in the district court challenging the legality of the actions by the procuring agency is six years. 28 U.S.C. $\S 2401$ (1970). As a practical matter, however, laches will probably be an effective bar to these suits long before the running of the statute of limitations. See Lombard v. Resor, 321 F. Supp. 687, 693 (D.D.C. 1970). See also 2 J. Moore, Federal Practice T 3.07[3] (1971).

The limitations period for suits brought in the Court of Claims to recover bid preparation expenses, see notes 47-51, 74-85 supra and accompanying text, is also six ycars. 28 U.S.C. $\S 2501$ (1970). This statute of limitations is not tolled while a plaintiff pursues any particular administrative remedy unless a statute requires that a particular administrative remedy must be exhausted. Air Express Inter'l Corp. v. United States, 439 F.2d 157, 159 (Ct. C1. 1971). Since a decision by the GAO on a bid protest is not a prerequisite to a suit in the Court of Claims to recover bid preparation expenses, a bid protest filed with the GAO does not toll the running of this six year statute of limitations in the Court of Claims. Id. at 159; Iran Nat'l Airlines v. United States, 360 F.2d 640, 642 (Ct. C1. 1966). See Mulholland v. United States, 361 F.2d 237, 243-44 (Ct. Cl. 1966). The commencement of an action in the district court, however, would toll the limitations period in the Court of Claims, See 2 J. Moore, FederaL Practice IT 3.07[6], at 789 (1971).

172. 2 K. Davis, Administrative Law Treatise $§ 18.11$ (1958).

173. Left open was the question of whether the court will ever be required to await a GAO determination. Wheelabrator Corp. v. Chafee, 455 F.2d 1306, 1316 n.16 (D.C. Cir. 1971). 
may not want his case decided by the GAO, he will be forced to seek such a decision under the doctrine of primary jurisdiction.

Since in our example the bids have already been solicited, opened, and the contracting officer has decided that the award should be made to $Y$, the chief advantage of bringing suit in the federal district court is to obtain an injunction against the award of the contract. Because $X$ can attempt to maintain the status quo through the use of a temporary restraining order and the preliminary injunction, he can effectively prevent the award of the contract to $Y$ while the case is pending before the court. In addition, if $X$ does receive a preliminary injunction, the application of the doctrine of primary jurisdiction will not be particularly harmful to $X$ since the contract cannot be awarded in the interim. ${ }^{174}$

\section{Bid Protest Is Filed Simultaneously in Both the GAO and the District Court}

$X$ may file suit simultaneously with the GAO and the district court; if he does so, $X$ may immediately be faced by the policy of the GAO, following Scanwell, not to hear any case which is also being litigated before a court of competent jurisdiction. ${ }^{175}$ The court, on the other hand, may decide the case on the merits. It is more likely, however, to follow the procedure set forth in Wheelabrator which encourages the court to issue a preliminary injunction pending GAO determination. Since the court would then be staying its proceeding, the GAO would be free to issue a decision on the merits of the case. ${ }^{176}$ Consequently, the best procedure available to $X$, if he has any hope of success on the merits, is to file a protest with the GAO while simultaneously requesting a preliminary injunction in a district court pending a decision on the merits of the protest filed with the GAO.

The most important consideration in bringing simultaneous suits is the possible res judicata effects of the decision in the district court. Assume, for example, that $X$ applies only for a temporary restraining

174. If the facts in the example were changed so that $X$ filed his suit in court after the contract had been awarded to $Y$, it would be imperative that $X$ get a preliminary injunction in order to prevent $Y$ from performing the contract. The extent of the performance on the contract is an important factor in determining whether a contract will be cancelled. See notes 97.98 supra and accompanying text.

175. See note 14 supra.

176. See notes 107-21 supra and accompanying text. 
order and a motion for a preliminary injunction pending a decision on the merits by the GAO. What res judicata effect, if any, does a denial of the temporary restraining order and the preliminary injunction have on the protest filed before the GAO? The denial alone will have no res judicata effect, since denial of a motion for a preliminary injunction is not an adjudication on the merits of the case; ${ }^{177}$ therefore, it does not bar the GAO from considering the matter. ${ }^{178}$ On the other hand, assume that $X$ requests not only that a preliminary injunction be issued pending GAO decision, but also that the court award him the contract should he fail in his protest with the GAO. If the court denies the motion for a preliminary injunction and dismisses the complaint, that dismissal is res judicata as to the issues set forth by the plaintiff in his motion. ${ }^{179}$ The GAO is then confined to hearing matters which were not at issue before the court when the complaint was dismissed. ${ }^{180}$ Thus, the best tactic for $X$ is to request only a preliminary injunction pending decision by the GAO in order to maintain the status quo; if that request is denied, there will be no res judicata effect either on the GAO or on the merits of the case in court.

\section{The EFfect of Scanwell And Its Progeny on the GAO}

The importance of the GAO has not been undercut by the emergence of the court as an alternative forum for unsuccessful bidders. Notwithstanding the Scanwell decision and its declaration that the GAO remedy need not be exhausted before filing a suit in the district

177. 7 J. Moore, Federal Practice T 65.04[3], at 1641; II 65.21, at 1703 (1971).

178. In Keco Indus., Inc. v. Laird, 318 F. Supp. 1361 (D.D.C. 1970), the district court was asked to enjoin the government from accepting any deliveries or making any payments under a government contract and to direct the awardee of the contract to stop work on the contract until the GAO decided the protest; also, if the decision of the GAO was unfavorablc, to dccide the case on the merits. The court denied the motion. The GAO then decided that the court's rejection of a preliminary injunction in a bid protest case does not constitute a decision on the merits that would bar the GAO from issuing a decision on the protest. Unpublished Opinion, B-170989, Nov. 17, 1971, discussed in 405 BNA FED. CONT. REP. A-13 (197I).

179. A dismissal not provided for by FED. R. CIV. P. 41(b) includes a dismissal by the court upon its own motion, and unless the court otherwise specifies in its dismissal ordcr, operates as an adjudication upon the merits. Safeway Stores v. Fannan, 308 F.2d 94, 99 (9th Cir. 1962). See 5 J. MoORE, Federal Practice II 4I.I4[I], at I173 (I97I). If the dismissal is with prcjudice, the judgment is a bar to another action by the plaintiff on the claim dismissed. Id. II $41.13[1]$, at 1149 .

180. Unpublished Opinion, B-171782, July 19, 1971, discussed in 387 BNA FED. CoNT. ReP. A-3 (1971). See Unpublished Opinion, B-171917, May 4, 1971. 
court, ${ }^{181}$ the number of bid protests filed with the GAO has continued to increase. ${ }^{182}$ This is probably due to the fact that the GAO procedure is usually less expensive, more informal, and far more expeditious than a court proceeding. ${ }^{183}$

Although Scanwell has not affected the volume of bid protests filed with the GAO, it has been a major influence in forcing the GAO to acknowledge criticisms of its procedures and to attempt to improve those procedures. ${ }^{184}$ The GAO was also made aware of the need to streamline its procedures because of the substantial number of cases in which contracts had already been awarded before the GAO rendered a decision. ${ }^{185}$ Thus, in December 1971, the GAO implemented new bid protest procedures ${ }^{186}$ designed to achieve speedier disposition of bid protests by imposing time limits on all parties involved, ${ }^{187}$ including the GAO itself and, to some extent, the contracting agencies. ${ }^{188} \mathrm{~A}$ total of seventy-one working days is allowed by the regula-

181. See note 171 supra and accompanying text.

182. In the fiscal year 1970-7I, 1054 cases were received by the GAO in contrast to 771 cases received in fiscal year 1969-70. Bid Protest Techniques 1. Of the 1054 cases received in 1970-71, formal decisions were rendered in 715; 614 protests were denied; 74 protests were sustained; 4 cancellations were recommended; and in 85 cases corrective action was recommended. Id.

183. See notes $46 \& 170$ supra and accompanying text; Cibinic \& Lasken 364.

184. In opening the courthouse doors to challenges of procurement determinations,

$S c a n w e l l$ provided protection against illegal governmental action. This was salutary not only for the relatively few cases that might result in court intervention, but also for the greater number of cases which would be handled with greater care and more diligence within the government because of the awareness of the availahility of judicial scrutiny.

M. Steinthal \& Co. v. Seamans, 455 F.2d 1289, 1301 (D.C. Cir. 1971).

185. 36 Fed. Reg. 8060 (1971).

186. 36 Fed. Reg. 24791 (1971). See 4 C.F.R. $\$ 20.1$-.12 (1972).

187. The bid protest must be filed with the GAO within five days after the basis of the protest is known or should have bcen known. Any additional material in support of the protest must he submitted within five days after the initial protest is filed. 4 C.F.R. $\$ 20.2$ (1972). The GAO must then give notice of the protest to the contracting officer within one day of receipt of the protest. Id. $\S 20.3$. The contracting agency has twenty days in which to submit its administrative report on the protest, $i d$. $\S 20.5$, as compared with the average of forty-five to fifty days which it took for the GAO to receive an agency report under the prior rules. Judicial and GAO Review of Bid Protest Cases 21. Recipients of this report, the protestant and other bidders, then have ten days within which to submit comments on the report to the GAO. 4 C.F.R. $\S 20.6$ (1972). The GAO may also request additional information from the interested parties to be submittcd within ten days of request. Id. $\S 20.7$. The GAO must render a decision within twenty days after the receipt of all the information submitted by the parties. Id. $\S 20.10$.

188. The GAO has no authority to impose time limitations on the contracting agencies, but the GAO requests that they agree to incorporate these time limitations within their own regulations. 36 Fed. Reg. 24791 (1971). 
tions from the time the protest is filed until the GAO renders its decision. However, this does not seem to be a significant improvement over the average ninety days it presently takes the GAO to decide a case. ${ }^{189}$ The new procedures also fail to meet criticisms that the GAO does not prohibit ex parte communications, accepts the government's version of the facts, and relies almost entirely upon written information without providing any opportunity for oral hearings. ${ }^{190}$ The GAO does attempt to meet partially the criticisms by furnishing the report of the agency to the bid protestant and by allowing the protestant, or any interested parties, to request a conference, which all parties can attend, regarding the merits of the protest with members of the Office of General Counsel of the GAO. ${ }^{101}$ With respect to GAO remedies, it is significant that the new regulations direct the procuring agency to withhold award of the contract until the GAO has rendered its decision unless the procuring agency furnishes a written statement specifying why the award of the contract cannot be delayed. ${ }^{192}$ While the GAO may not be able to compel compliance with the policy directly, it can withhold disbursement of funds when it deems a contract to have been awarded improperly. ${ }^{193}$

Although Scanwell and its progeny have had a marked influence on the GAO bid protest procedure, they have effectuated very little change in the substantive law in the procurement area as developed by the GAO. ${ }^{194}$ This is evident in a comparison of court decisions with GAO treatment of the same or similar cases. Blount-Barfell-Dennehy v. United States ${ }^{195}$ is the only case not reversed on appeal in which a

189. Bid Protest Techniques 9.

190. Letter from Roy S. Mitchell, Chairman, Bids \& Protests Committee, Section of Public Contracts Law, American Bar Association, 381 BNA Fed. Cont. ReP. D-1 (1971); id. A-6; 385 BNA FED. CONT. REP. A-3 (1971); see notes $43-46$ supra and accompanying text. However, Mr. Paul Dembling, General Counsel, GAO, has suggested that the GAO may be influenced by the more objective evaluation of facts in the federal courts as opposed to the traditional GAO presumption that administrative positions are correct and that the GAO may become freer with cancellation of contracts which are found to be improperly awarded in order to overcome the GAO's paper tiger image. Judicial and GAO Review of Bid Protest Cases 2122.

191. 4 C.F.R. $\$ 20.6,20.9$ (1972). The foregoing criticisms of the GAO, moreover, may be overly harsh inasmuch as they are directed at two incompatible goals-speed and due process.

192. Id. § 20.4.

193. See note 30 supra and accompanying text.

194. See generally Judicial and GAO Review of Bid Protest Cases.

195. Civil No. 70-392 (W.D. Okla., Aug. 6, 1970). 
party, subsequent to a denial of relief by the GAO, was granted affirmative relief by a district court. ${ }^{196}$ Even in Blount, the disagreement between the district court and the GAO was more apparent than real. The district court indicated that it would uphold the GAO decision; the procuring agency, however, consented to a judgment directing the award to the protestant. ${ }^{197}$ In Simpson Electric Co. $v$. Seamans, ${ }^{198}$ the district court reached a result contrary to that of the GAO, but the court did not give the plaintiff any affirmative relief since the contract was short-term and a substantial part of the contract had already been performed.

In a third category involving cases which were not decided by the GAO, the courts have also reached results which were nevertheless substantively consistent with other GAO decisions. In Lloyd Wood Construction Co. v. Sandoval, ${ }^{199}$ an unsuccessful bidder challenged the eligibility of the low bidder to receive a small business set-aside contract on the ground that the low bidder did not qualify as a small business. The Small Business Administration (SBA) had decided that the bidder was a small business; howevcr, the District Court for the Northern District of Alabama held that the accounting method employed was erroneous and that as a matter of law the low bidder was not a small business when the correct accounting method was used. $\mathrm{Had}$ the GAO heard this case, it would probably have agreed with the SBA inasmuch as the GAO has refused to question SBA determination of size requirement eligibility in the absence of fraud or bad faith. ${ }^{200}$ However, the GAO's practice of accepting such SBA deter-

196. In all the other cases decided by the court subsequent to a GAO determination, the court has reached the same decision as the GAO. Wheelabrator Corp. v. Chafee, 455 F.2d 1306 (D.C. Cir. 1971); M. Steinthal \& Co. v. Seamans, 455 F.2d 1289 (D.C. Cir. 197I); A.G. Schoonmaker Co. v. Resor, 445 F.2d 726 (D.C. Cir. 1971); Page Communications Eng'rs, Inc. v. Resor, 15 CCH Cont. CAS. F. I 84,154 (D.C. Cir., Dec. 4, 1970); Lombard Corp. v. Resor, 312 F. Supp. 687 (D.D.C. 1970). This category includes the cases in which the district court initially disagreed with the GAO but was reversed on appeal. Wheelabrator Corp. v. Chafee, supra; M. Steinthal \& Co. v. Seamans, supra; A.G. Schoonmaker Co. v. Resor, supra.

197. See notes $99-101$ supra and accompanying text.

198. See notes 93-98 supra and accompanying text.

199. 318 F. Supp. 1167 (N.D. Ala. 1970).

200. Judicial and GAO Review of Bid Protest Cases 9. The administrator of the SBA is given the power to make rules and regulations to carry out the policy of the Small Business Act. 15 U.S.C. $\$ 634(b)(6)(1970)$. The SBA regulations provide a detailed procedure for determining the size of a business, and for contesting a size determination. I3 C.F.R. pt. 12I (1971). Thus, Congress has committed the determination of what businesses come within the scope of the Small Business Act to the executive branch. Allen M. Campbell Co. v. Lloyd Wood 
minations was followed when the Court of Appeals for the Fifth Circuit reversed, holding the SBA finding conclusive on the issue of size for eligibility for small business contracts. ${ }^{201}$

Court rulings and GAO decisions will likely continue to cohere since the District of Columbia Circuit has applied the doctrine of primary jurisdiction to the GAO. This similarity of results gives added support to the conclusion that an unsuccessful bidder should continue to file his protest with the GAO and use the district court to obtain temporary relief in order to preserve the status quo. ${ }^{202}$

Because the application of the doctrine of primary jurisdiction limits the discretion of the court and increases the likelihood that it will reach the same result as the GAO, it is possible that a bidder will want to challenge the jurisdiction of the GAO. The federal courts have, to be sure, recognized that the GAO in effect decides bid protest cases. However, they have never specifically been forced to decide the authority of the GAO to determine the legality of a contract award. ${ }^{203}$ In John Reiner \& Co. v. United States, ${ }^{204}$ the Court of Claims, without explicitly deciding the issue, stated that the decision of the GAO could be used as a basis for cancelling a contract under the termination for convenience clause to avoid conflict with another branch of the government. ${ }^{205}$ The court in Schoonmaker relied on

Constr. Co., 446 F.2d 261, 265 (5th Cir. 1971).

201. 446 F.2d 261 (5th Cir. 1971). In Floyd F. Miner Security Servs. Inc. v. Paine, Civil No. 2236-70 (D.D.C., Aug. 17, 1970), discussed in 337 BNA FED. CoNT. REP. A-11 (1970), the court also upheld the size determination by the Small Business Administration.

202. See notes 175-76 supra and accompanying text.

203. "We are not required to determine the issue of the extent of the authority of the GAO which may be inferred from the function of settling accounts or other responsibilities." Wheelabrator Corp. v. Chafee, 455 F.2d 1306, 1314 (D.C. Cir. 1971). "We are not called upon to make a formal determination concerning the controversy over the legal authority of the Comptroller General to issue decisions in bid protests, and the effect of such determinations on agency procurement policies." M. Steinthal \& Co. v. Seamans, 455 F.2d 1289, 1298 (D.C. Cir. 1971). "[W]e do not reach the problem of the authority of the Comptroller to issue decisions in bid protests." A.G. Schoonmaker Co. v. Resor, 445 F.2d 726, 728 n.3 (D.C. Cir. 1971).

204. 325 F.2d 438 (Ct. C1. 1963).

205. The contracting officer did not agree with that opinion, but it is the usual policy, if not the obligation, of the procuring departments to accommodate themselves to positions formally taken by the General Accounting Office with respect to competitive bidding. That Office as we have pointed out, has special concern with, and supervision over, that aspect of procurement. It would be entirely justifiable for the contracting officer to follow the general policy of acceding to the views of the Accounting Office in this area even though he had another position on the particular issue of legality or propriety. He would not be allowing the Comptroller General to dictate the termination 
Reiner, thereby reaffirming this analysis. ${ }^{206}$ The court has specifically stated, however, that "[o]ur opinion as to the value and significance of determinations of the Comptroller General, when available, is not inconsistent with our prior ruling that a bidder who is unable to obtain effective relief from the Comptroller General is not required to exhaust that remedy as a prerequisite to judicial review."207

That the court has given its strong support to the GAO by applying the doctrine of primary jurisdiction without ever actually deciding the crucial issue of the authority of the GAO to decide bid protest cases is somewhat anomalous. Yet, whether or not the GAO has the actual authority to decide bid protest cases, the application of the doctrine of primary jurisdiction to the GAO still seems justifiable since the court recognizes administrative expertise as the underlying rationale of the primary jurisdiction doctrine, and the GAO has developed an expertise in the area of government procurement. ${ }^{208} \mathrm{By}$ adopting this position, the federal courts have left the jurisdiction of the GAO almost entirely intact. Nevertheless, because the courts are giving such weight to its decisions, the authority of the GAO will likely be challenged by an unsuccessful bidder in the future. ${ }^{209}$

of the contract but, rather, would be using termination as a means of minimizing a conflict with another arm of Government properly concerned with the contractual problem. It cannot be contrary to "the best interests of the Government"-the controlling standard of the termination clause-to end a contract which the Comptroller General has branded as incorrectly advertised. Id. at $442-43$ (footnotes omitted).

206. 445 F.2d 726, 728 n.3 (D.C. Cir. 1971). The court subsequently relied on this analysis in M. Steinthal \& Co. v. Seamans, 455 F.2d 1289, 1304-05 (D.C. Cir. 1971).

207. M. Steinthal \& Co. v. Seamans, 455 F.2d 1289, 1298 n.27 (D.C. Cir. 1971).

208. See notes 108-10 supra and accompanying text.

209. Cf. ITT v. Seamans, C.A. No. 1035-7I (D.D.C. June 29, 1971), in which the court denied a motion by the GAO to intervene in a case contesting the right of the Air Force to award part of a contract to a low bidder previously rejected on the advice of the GAO. Unpublished Opinion, B-170426, Feb. 10, 1971. The court based its denial on a finding that the GAO had no legal interest in the proceeding before the court. The Justice Department's Memorandum in Opposition to Comptroller General's Motion for Leave to Intervene argued that the GAO had no legal interest in the proceeding since its opinions were only advisory, that no official function of the GAO could be impaired since the Comptroller General cannot award any contract, and the statutes and regulations involved are to be administered by the procuring agency and not the Comptroller General. In making this decision, however, the court was still not forced to decide whether the GAO in fact has authority to decide bid protest cases.

The court's holding that the GAO has no right to intervene could be negated by two bills presently before the Senate. These bills would allow the Comptroller General to bring suit in the District Court of the District of Columbia whenever he has reasonable cause to believe that any officers or employees of the executive branch are about to expend or obligate public funds in an illegal manner. S. 1022, 92d Cong., Ist Sess. (1971); S. 2702, 92d Cong., Ist Sess. (197I). 


\section{CONCLUSION}

By opening the judicial forum for review of a claim of illegality in the award of a contract, the court in Scanwell substantially improved the availability of effective relief for the disappointed bidder. Nevertheless, the initial impact of Scanwell has been softened by subsequent court decisions. Without retreating from Scanwell, the Court of Appeals for the District of Columbia has, in the last analysis, heeded the cautionary attitude taken by Justice Black in Perkins v. Lukens Steel Co. ${ }^{210}$ concerning the undesirability of judicial interference with the government's procurement process. ${ }^{211}$ The restraints placed on judicial review have basically been founded on the concern of the court that it would be flooded by a large number of cases involving highly technical decisions. ${ }^{212}$ From the point of view of the unsuccessful bidder, resort to the judicial forum has also been unsatisfactory. The litigation has been expensive, and affirmative relief has been obtained in only one case. However, now that the court of

The main purpose of these bills is to give the Comptroller General recourse to the courts whenever the Attorney General disagrees with the position of the GAO and refuses to argue its position in a judicial proceeding. The genesis of these bills was the dispute over the Administration's Philadelphia Plan. The Comptroller General ruled that federal contracts containing mandatory hiring quotas were illegal. The Attorney General supported the Administration's position, and the GAO found itself without a remedy. A rider was attached by the Senate to the Supplemental Appropriation Act of 1970, P. L. No. 91-166 (Dec. 26, 1970), which would have precluded the award of any contract that the Comptroller General deemed illegal. The rider was withdrawn when President Nixon threatened to veto the bill. 358 BNA FED. CoNT. REP. K-2 to K-3 (1970).

The bills call for a sixty-day waiting period during which the Comptroller General could not file suit in order to give the Committee on the Judiciary and Government Operations of the House and Senate an opportunity to review the matter and recommend, if it wishes, that the suit not be brought. These bills, however, seem to have little relevance to the bid protest area of the procurement process. Since the unsuccessful bidder has standing to challenge the award or proposed award of a contract, he would have little need or incentive to wait for the GAO to initiate an action. Moreover, the effectiveness of the GAO action may be impeded by the provision that it must wait for sixty days before the suit can be filed. During the sixty-day interim period, the contract may have already been awarded and performance substantially begun.

For a general discussion of these two bills and possible constitutional problems, see 400 BNA Fed. Cont. ReP. A-9 (1971); 358 BNA Fed. Cont. ReP. K-1 (1970).

210. 310 U.S. 113, 127-32 (1940). "The interference of the Courts with the performance of the ordinary duties of the executive departments of the Government, would be productive of nothing but mischief. . . ." Id. at 131-32 (quoting Decatur v. Paulding, 40 U.S. (14 Pet.) 497 , $516(1840))$.

211. 455 F.2d 1289, 1305 (D.C. Cir. 1971).

212. M. Steinthal \& Co. v. Seamans, 455 F.2d 1289, 1301-02 (D.C. Cir. 1971). 
appeals has in Steinthal laid out the standard of review to be applied by the courts and in Wheelabrator encouraged the use of the preliminary injunction in connection with the GAO remedy, resort to the courts to determine the merits of the case will probably no longer be taken as a matter of course.

The Court of Claims, probably influenced by Scanwell, extended its implied contract theory to give standing to a disappointed bidder in all procurement situations where no rational basis existed for the actions of the procuring agency. However, the Court of Claims has subsequently adopted the "rational basis" standard of review enunciated in Steinthal by the court of appeals, and has refused to enlarge the available remedy beyond recovery of bid preparation expenses. Consequently, the Court of Claims will continue to play a subordinate role in the adjudication of bid protests.

The GAO has remained substantially unaffected by the opening of the judicial forum to bid protests; consequently, most of the former inadequacies of its bid protest procedures remain intact. While the GAO has made major procedural improvements-time limitations, withholding of contract awards, and providing for conferences with the parties to the protest-these changes fail to meet the major criticisms that the GAO's procedures are insufficiently expeditious; do not adequately establish due proeess criteria; and do not provide adequate relief, absent power to withhold award of a contract pending resolution of a bid protest. ${ }^{213}$

The substantive precedents established by GAO decisions have also been left intact by court challenges. Since the role of the GAO and its expertise in government procurement have been given important support and recognition by the decisions in Steinthal and Wheelabrator, without any significant criticisms, the GAO has little incentive to change its present modus operandi. ${ }^{214}$ Moreover, it is not clear that the GAO has any obligation to initiate changes in the federal procurement system, inasmuch as its involvement in federal procurement is a fortuitous result of the lack of any other forum in which a bid protest can effectively be made.

Thus, it appears that any significant reform must develop outside the present bifurcated system. The frustration and growing dissatis-

213. Roy S. Mitchell, supra note 190. See also note 218 infra.

214. See Judicial and GAO Review of Bid Protest Cases 22-23. 
faction among the members of the procurement bar ${ }^{215}$ with existing methods and procedures have led to some pressure for the development of legislation to produce a satisfactory solution. Procurement lawyers are hopeful that the Commission for Government Procurement, ${ }^{216}$ which is presently engaged in reviewing the entire procurement field, will propose substantial legislation to change the entire system. ${ }^{217}$ Suggested approaches to the problem include strengthening the authority of the contracting officer, providing for a right to money damages for lost profits, adding to the remedies available to the GAO, and, more far reaching, the establishment of a new administrative authority or court solely to handle bid protests. ${ }^{218}$

In Steinthal and Wheelabrator, the Court of Appeals for the District of Columbia has set forth a well-defined position limiting judicial interference, from which it seems likely there will be no radical departures in the foreseeable future; nor does it seem likely that the GAO will soon propose any additional changes in its procedure. Yet, the remedial dilemma facing the procurement community still exists and will continue to exist unless Congress is prodded to reach a legislative solution.

215. 381 BNA Fed. CONT. ReP. D-1 (1971).

216. 41 U.S.C. $\S 251$ (1970).

217. An overriding issue in bid protest procedures is how to reduce procedural delays and make the decisions more timely, while according all interested parties a fair opportunity to state their positions....

....

The question has also been raised whether adjudicative machinery should be established which relieves the Comptroller General of the burden of bid protest adjudications and permits him to devote more time to other duties. H.R. REP. No. 468, 91 st Cong., 1st Sess. 30 (1969).

218. 378 BNA FED. CONT. REP. A-3 (1971). Suggested improvements in GAO remedies are: prohibiting ex parte communications; reviewing protests de novo with no presumptions running in favor of the government; allowing full discovery adjudicatory-type hearings if requested; and avoiding excessive reliance on written data submitted by the procuring agency. Roy S. Mitchell, supra note 190. 